\title{
Genel ve Karşılaştırmalı Edebiyat Bilimi'nin (Komparatistik) Ulusal ve Dünya Edebiyatları Ekseninde Kuramsal Açılımı
}

\author{
Doç. Dr. Ahmet Cuma \\ Selçuk Üniversitesi Edebiyat Fakültesi \\ Karşılaştırmalı Edebiyat Bölümü \\ ahmetcuma@selcuk.edu.tr
}

Öz

Karşılaştırmal Edebiyat Bilimi genel olarak Komparatistik ile aynı olarak kabul edilmektedir. Ancak konuyu derinlemesine ele alan kaynaklara bakıldığında aynı şeyler olmadığı görülmektedir. Ayrı birer disiplin olmalarına rağmen birbirlerine bağımlı ve bundan dolayı sürekli birlikte hareket eden Genel Edebiyat Bilimi ile Karşılaştırmalı Edebiyat Bilimi'nin bir bileşkesi olan Komparatistik, edebiyat eleştirisi ve buna bağlı olarak edebiyat tarihi yazıcılığının gelişmesine vazgeçilemeyecek katkılar sağlayarak, ulusal edebiyatların dünya edebiyatı içindeki konumunun belirlenmesinde yadsınamayacak imkânlar sunmaktadır. Böylelikle, Genel ve Karşılaştırmalı Edebiyat Bilimi olarak da ifade edilen Komparatistik, Edebiyat Bilimi altında bağımsız bir disiplin olmakla birlikte ulusal filolojilere önemli katkılarda bulunmaktadır. Bu çalı̧̧mada Komparatistik'in söz konusu edilen etki gücünü açılayabilmek için dört kavram düzeyi ele alınmıştır; bunlar Genel ve Karşılaştırmalı Edebiyat Bilimleri, Ulusal ve Dünya Edebiyatlarıdır. Bu bağlamda yanlış algılara sebep olan bir başka hususa da değinilmiştir: Komparatistik'in temel unsurlarından birini teşkil eden karşılaştırma eylemi asıl amaç değil, bilgiye ulaşmak ve analitik düşünceyi desteklemek için bir başlangıç noktasıdır. Genetik ve tipolojik karşılaştırmalar başka disiplinlerin yardımıla metin odaklı incelemeleri insan algısına daha uygun hale getirir. Komparatistik'in sağladığı bu imkânları görmezden gelmek, ulusal edebiyat ürünü olan nitelikli eserlerin dünya edebiyatı içinde konumlandırılmasında, olumsuz yönde etki edebilir.

Anahtar Kelimeler: Komparatistik, karşılaştırmalı edebiyat, genel edebiyat, ulusal edebiyat, dünya edebiyatı.

\section{Theoretical Explanation of General and Comparative Literature (Komparatistik) in the Context of National and World Literature}

\begin{abstract}
Although Literature and Comparative Literature are two different disciplines, they are interrelated and continuously act together. Comparative Literature (in German: Komparatistik), the consolidation of these two disciplines providing indispensable contributions to literary criticism along with the development of literary historiography, provides opportunities for determining the place of national literatures in world literature.
\end{abstract}


Thus, Komparatistik has significant contributions to national philology as an independent discipline of literature. In this study, four concepts have been investigated to explain Komparatistik's power of influence; literature, comparative literature, national literatures, and world literatures. To this end, another issue that causes frequent misperceptions has been investigated; the act of comparison constituting one of the basic elements of Komparatistik is not the main objective but a starting point for reaching knowledge and supporting analytical thinking. With the help of other disciplines, genetic and typological comparisons make the text-based studies more suitable for human perception. The ignorance of these opportunities provided by Komparatistik may have a negative impact on National Literatures and cultural developments.

Keywords: Komparatistik, comparative literature, general literature, national literature, world literature. 


\section{GíRIŞ}

Karşılaştırma eylemi sadece Genel ve Karşılaştırmalı Edebiyat Bilimi'nin (Komparatistik) değil, başka birçok bilim dalının da uygulama alnında, önemli bir aşamasını teşkil etmektedir. Filoloji de bu alanlardan birisidir. Her yeni bulgu elde edilmeden önce kendinden önceki benzer görüngülerle bir karşılaştırma sürecine tabi tutulur. Dünyayı algılamamıza aracilık eden ve dolayısıyla yorum bilimin (Hermeneutik) temel hareket tarzını belirleyen bütün tarihsel ve sistematik düzenlemelerin özünde karşılaştırma odaklı benzer anlamlandırma eylemleri vardır.

Komparatistik'in karşılaştırmaya odaklı çalışma tarzının genel geçer bir eylem olduğu bellidir. Edebiyata uyarlandığında, karşılaştırmalı bakış açısı sadece okuyucuya değil, yazara da büyük ölçüde yön vermektedir. Çünkü her metin, yazarının diğerleriyle yaptığı kendi karşılaştırmalarıyla örülüdür. Fakat yazar odaklı etki olayında iz sürme araştırmaları için öncelikle, bilimselliğin bir gereği olarak, eser odaklı bir çıkış noktası gereklidir. Evi Zemanek'in belirttiğine göre Komparatistik çalışmalarında karşılaştırmak demek ne eşitlik (Gleichheit) ne de eşitleme (Ausgleich) demektir. Zemenek, Grimm sözlüğünde yapılan bir açıklamadan hareketle karşılaştırmayı alıntılayarak açıklamıştır: "tanımayı mümkün kılan benzerliklerin yan yana getirilmesi" (nebeneinanderstellung, aus welcher ähnlichkeiten erkannt werden können) (Grimm 2016). Ona göre benzerlikler ele alınırken, Komparatistik'i aynı derecede ilgilendiren farklılıklar da kendiliğinden ortaya çıkmaktadır (Zemanek-Nebrig 2012: 14-15).

Gürsel Aytaç'ın belirttiğine göre “karşılaştırmalı edebiyat biliminin temelinde öteki karşılaştırmalı bilim dallarında olduğu gibi, karşılaştırma yöntemi vardır" (Aytaç 2003: 13). Aytaç bu açıklamayı yaptıktan sonra karşılaştırma yönteminin bilimde kullanılmadan önce de insanın düşünce tarzında var olduğunu belirtmiş ve atasözlerinin insanın karşılaştırmaya ne kadar yatkın olduğunu gösterdiğini belirtmiştir. Karşılaştırmanın bilimsel bir metot olarak kabul edildikten sonra öncelikle sosyal bilimlerde kullanıldığını belirten Aytaç, örnek olarak Goethe'nin karşılaştırmalı anatomi yazısını (Erster Entwurf einer allgemeinen Einleitung in die vergleichenden Anatomie) vermiştir. Goethe'nin bu yazısının 'tabiat tarihi zaten karşılaştırmaya dayanır' cümlesiyle başladığını belirten Aytaç, daha sonra Carus'un "Lehrbuch der vergleichenden Zootomie" (Karşılaştırmalı Hayvan Anatomisi Ders Kitabı), Bopp'un "Vergleichende Sprachwissenschaft" (Karşılaştırmalı Dilbilim), Julien'in karşılaştırmalı pedagojinin ilk taslağını yazdığını ve Mostesquieu'nün hukuk gelişim ilkelerini saptarken, yasaların sınıflandırılmasında karşılaştırmadan yararlandığını örnek olarak vermiştir (Aytaç 2003: 13-14). Ayrıca Cemal Sakallı 18. yüzyılda doğa bilimlerinde, öncelikle fizyoloji ve anatomi alanlarında, karşılaştırmalı çalışmaların artmasının, karşılaştırmalı bakış açısına yeni yönelimler kattığını ve karşılaştırmalı edebiyat çalışmalarının artmasında sebep olduğunu belirtmiştir (Sakallı 1998: 19). Görüldüğü gibi, karşılaştırma neticesinde elde edilen benzerlik ve farklılıklar birçok bilim dalında bilginin en temel kaynağı olarak kabul edilmiştir. İnsanın doğasında var olan, pratik bir yöntem olmasından ve üretme veya bilgiye en kısa yoldan ulaştırma karakterine sahip olmasından dolayı birçok bilimsel disiplinde, geçmişten günümüze kadar karşılaştırma tercih edilmiştir ve edilmektedir.

Yapı bakımından karşılaştırma, doğal olarak en az iki öğeden meydana gelmektedir. Ortaklıklar fark edilip mantık düzleminde karşı karşıya getirilir. Böylelikle bilinen birinden hareketle diğeri öğrenilmeye/anlaşılmaya çalışılır. Fakat karşılaştırma hiçbir zaman asıl amaç olmamalı, öncelikli olarak bilgiye ulaşmak gaye edinilmelidir. Aksi takdirde salt karşılaştırma odaklı analitik düşünceyi desteklemeyen bir eylemden ileri gidilemez. 
Karşılaştırmalı edebiyat biliminin önemli okullarından biri olan Fransız Ekolü, en fazla bundan dolayı eleştirilere maruz kalmıştır. Fransız karşılaştırmacılığında kendi içine kapalı, bağımsız ulusal edebiyatların varlı̆̆ 1 kabul edilir. Fransız ekolünün temel düsturu olan bu düşünce pozitivizm ekseninde tesir konusuna yoğunlaşarak karşılaştırma eylemini edebilik ölçüleri dışına çıkma tehlikesini doğurabilir düşüncesi ve karşılaştırma eylemini bir belirsizliğe doğru açımlayacağı endişesinden dolayı eleştirilir (Zima 1992: 17, 26; Aytaç 2003: 74, 84). Çünkü bu durum karşılaştırmanın asıl amaç olduğu, etki-etkilenme olayında iz sürmenin gaye edildiği ve doğru bilgiye ulaşmanın arka plana itildiği izlenimini uyandırmaktadır.

Edebiyat bilimi için belge niteliğindeki bulguların uluslararası benzerlikleri, ulusların toplumsal ve edebi gelişimlerinin paralelliğine, ayrıca birbirleriyle olan kültürel ve edebi temaslarına dayanmaktadır. Bazı karşılaştırmalı çalışmalar kültür farklılığına ve edebiyat dışı koşullara rağmen benzerliklerin olabileceğini göstermeye çalışır; bazı çalışmalar ise aynı zaman diliminde meydana gelmiş olan eserlerin estetik ve kültürel olarak ne kadar farklı olabileceğini kanıtlamayı amaçlar. Bunların dışında kültürlerarası veya tarihler arası bağlamları yeniden yapılandırma ve bir görüngünün benzersiz olduğunu göstermeye çalışan araştırmalar da vardır. Eğer bir karşılaştırma ortaklıklara yoğunlaşıyorsa eşdeğer karşılaştırmadan (äquivalenten Vergleich), farklılıklara odaklanıyorsa karşıtlık karşılaştırmadan (kontrastiven Vergleich) söz edilir. Farklı yapıda karşılaştırmalar olduğu için Komparatistik çalışmaları sistematik olarak kategorize edilmiştir. En bilinen sınıflandırma genetik ve tipolojik karşılaştırma çeşitleridir. Genetik karşılaştırma, doğrudan veya dolaylı olarak meydana gelen temas neticesinde oluşmuş olan, benzerlikleri araştırırken tipolojik karşılaştırma hiçbir temas olmadan benzer üretim koşullarından kaynaklanan ortaklıklara yoğunlaşır (Zemanek-Nebrig 2012: 16-17; Zima 1992: 105-182).

Edebiyatların karşılaştırılmasını daha sağlam bir yapıya dayandırma eğilimi, günümüzde disiplinlerarasılık ilkelerinden hareketle sağlanmaya çalışılmaktadır. Peter Václav Zima'ya göre edebiyat sosyolojisi, edebiyat psikolojisi ve metne dayalı dilbilimsel teoriler ile metotlar, edebiyat karşılaştırmasını somutlaştırmaktadırlar. Örneğin, kültür semiyotiği ile metin semiyotiği bağlamında düşünüldüğünde, değişik kültürlerde farklı edebiyat ve metin kavramları karşımıza çıkmaktadır. Zima, Rus edebiyat ve semiyotik bilimcisi Juri Michailowitsch Lotman'ın tespitinden hareketle, iki önemli hususa dikkat çekmektedir. Birincisi, karşılaştırmanın gerçekleştirildiği teorik bağlamın karşılaştırılan metinlerden daha önemli olduğudur. İkincisi ise, bütün metin bilimlerinin olduğu gibi karşılaştırmalı edebiyat biliminin de sosyal bilimlerle olan ilgisidir; özellikle dilbilimi, antropoloji ve sosyoloji ile. Birinci argüman karşılaştırmalı edebiyat biliminin çalışma alanıyla doğrudan ilgilidir ve bilhassa Amerikan temsilcileri tarafından Karşılaştırmalı Sanatlar olarak ifade bulmaktadır. René Etimble bunu dünya edebiyatının teorisi olarak algılamıştır. Etimble'ye göre gerçek karşılaştırmalı edebiyat bilimi bütün insanlığın edebiyat yapıtlarını araştırmaya dâhil eder. Zima'ya göre Etimble bu düşüncesiyle, Goethe'nin teorik anlamlandırma çabasını önemsemeksizin insancıl amaçlar ve ideolojik öğreti idealiyle oluşmuş olan Dünya Edebiyatı anlayışını görmezlikten gelmektedir. İkinci argümana göre ise yazılı metnin toplumsal işlevi edebiyat biliminin sınırlarını aşmaktadır. Çünkü metin türlerinin kurumsallaştırılması ile toplumsal sistemin iletişim sorunsalına temas edilmektedir (Zima 1992: 8-9). Görüldüğü gibi Komparatistik bağlamında birçok konu tartışılmıştır ve tartışılmaya devam edilmektedir. Bu tartışmaların özellikle kuramsal bir düzlemde cereyan ettiği belirgindir. Bunun için öncelikle yaygın olarak Komparatistik 
yerine kullanılan Karşılaştırmalı Edebiyat Bilimi'nin gerçekten aynı şeyler olup olmadığı belirlenmelidir. Bunu tespit edebilmek için araştırmaları Genel Edebiyat Bilimi, Ulusal Edebiyat ve Dünya Edebiyatı kavramları bağlamında açmakta fayda vardır.

\section{GENEL EDEBİYAT BİLIMİ}

Genel edebiyat biliminin ne olduğu, neyi amaçladığı ve sağladığı hususlarla ilgili zaman zaman çelişkili, farklı görüşler ileri sürülmüştür. Bu açıklamaların bazıları çok net bir algılamayı mümkün kılarken bazıları müphem bir izlenim arz etmektedir. Hugo Dyserinck genel edebiyat bilimi ile ilgili net bir açıklamada bulunmaktadır. Ona göre bu kavramdan, ulusal edebiyatlara analog olarak problem tespiti yapan ve çözüm arayışında bulunan, bunun için ise tek bir edebiyatın geçerliliğini aşarak genel olana yönelen, edebiyat teorisi araştırmalarının bir alt alanı anlaşılmalıdır. Bu düşünceye göre genel edebiyat bilimi, bütüncül olan edebiyat biliminin bir parçasıdır ve başka bir bilim alanının zemininde edebiyat malzemesini kullanarak o alana fayda sağlamaya çalışan bir araştırma alanı değildir. Dyserinck bu açıklamalarını bir örnekle netleştirmektedir. Ona göre Genel Edebiyat Bilimi felsefenin bir alanı olan estetik ile edebiyatın malzemesini bir araya getirerek edebiyat yararına bir uğraşta bulunabilir (Dyserinck 1991: 150). Diğer taraftan genel edebiyat bilimi gerek kendi zihniyeti gerekse metodu bakımından ulusal filolojilerden farklıdır. Tek bir filolojiye bağlı teorik ve sistematik problemleri irdeleyen alan araştırmalarının ötesinde ulusal üstü özel araştırmalar da vardır. Genel edebiyat bilimi bunlardan biridir. Bu disiplin ulusal üstü bir düzlemde birçok ulusal edebiyatı eşzamanlı olarak ele alır ve önemli çözümler üretebilir. Genel edebiyat bilimi kavramını kullandığımızda kastedilen budur. Ulusal üstü çalışma neticesinde ulusal edebiyatlar için de önemli olan birçok belirleme yapilabilir:

"Der eigene Charakter des komparatistischen Teilgebiets, das demnach als "Allgemeine Literaturwissenschaft" bezeichnet werden kann, besteht also - genau wie dies für die vergleichende Geschichtsschreibung der Fall ist - in der Kombination des supranationalen Standorts mit dem multinationalen Gegenstand." (Dyserinck 1991: 150)

(Komparatistik'in yan alanı olarak tarif edilen 'Genel Edebiyat Bilimi'nin özgün karakteri -Karşılaştırmalı Tarih Yazıcılığı için de aynı derecede geçerli olan ulusal üstü bir konumun çok uluslu çalışma alanından meydana gelen bir kombinasyondur $)^{*}$

Edebiyatın etkisi ve fonksiyonunu belirleme bakımından toplum ve edebiyat ilişkisi örnek olarak verilebilir. Edebiyatın ne kadar toplumun bir yansıması olduğu ve topluma ne derece etki ettiği meselesi yakın zamandan beri artan bir ilgiyle sorgulanmaktadır. Edebiyatın toplum tarafından algılanışı edebiyat sosyolojisinin devamı niteliğindeki alımlama araştırmaları bağlamında somutlaştırılmaya çalışılmaktadır. Toplum-Edebiyat ilişkisi genellenerek edebiyat, bilimsel bir temele oturtulmaya çalışıldığı an ulusal üstü bir tavrın gerekliliği ortaya çıkar. Toplumun edebiyatın oluşmasındaki etkisi veya edebiyatın toplumu etkilemesi meselesi aslında ayn izlek, yani edebiyatın toplum tarafından nasıl algılandığı sorusu etrafında dolaşmaktadır. Bu alan yakın zamandan beri edebiyat sosyolojisince genişletilmiş olan alımlama araştırmaları (Rezeptionsforschungen) tarafından yürütülmektedir. Edebiyat sosyolojisi şimdiye kadar daha çok üretim estetiği

*Almancadan Türkçeye çeviriler tarafımdan yapılmıştır. 
(Produktionsästhetik) ile uğraşırken 20. yüzyılın 50'li yıllarında uluslararası bir istikamete yönelmiş ve artarak edebiyatın toplum üzerindeki etkisi ve buna bağlı olarak salt edebiyatın alımlanması konusuna ağırlık vermiştir. Bu bağlamda Bordeaux Üniversitesi karşılaştırmalı edebiyat bilimcilerin katkısı büyük olmuştur. Bunlardan en önemlisi 1958' de yayınlanmış ve ağırlıklı olarak Fransız karşılaştırmacılığına dayanan "Edebiyat Sosyolojisi" (Sosyologie de la Littérature) başlıklı çalışmasıyla yeni bir program ortaya koymuş olan Robert Escarpit'tir. $\mathrm{Bu}$ tür çalışmalardan teorilerin ancak edebiyat eserlerine dayandırıldığında gelişebildiğ anlaşılmaktadır. Bunun gibi ampirik uygulamaların çok kültürlü yapılanması ve gelişimini sürdürebilmesi için, özellikle kültür ve dil kısıtlamasına gidilmeksizin, değişik dil bölgelerinde gerçekleştirilmelidir. Genel edebiyat bilimi bağlamında edebiyat-toplum ilişkisi meselesini sadece tek bir dildeki edebiyat eserlerine dayanarak cevaplamak anlamsız bir uğraştır. Mme de Staël, Hippolyte Taines ve Georg Lukacs'ın çalışmalarında olduğu gibi, bu konuya odaklandıkça genel edebiyat bilimine dair soru ve görüşleri açıklamak için mutlaka Komparatistik bakış açısına yönelmek gereklidir. Araştırmacı sadece bir ülke edebiyatında geçerli olan bulgulara ulaşmak için uğraşmaz, diğer birçok ülke edebiyatına da yönelmek zorunda kalır ve bunun sonucunda karşılaştırmak kaçınılmazdır. Çünkü kesin yargılara ancak metinleri ve değişik görüşleri kıyaslayarak ulaşılır (Dyserinck 1991: 152-155).

Kesin olan şudur: Genel Edebiyat Bilimi ulusal üstü çalışır ve sadece ulusal edebiyatlarla değil, edebiyat ile diğer alanların ilişkisini de inceler. Edebiyat ile diğer alanların ilişkisini incelemek özellikle Amerika Birleşik Devletleri'nde (ABD) rağbet görmektedir ve en önemli temsilcisi Henry Remak'tır. Remak genel edebiyat biliminin zayıf bir noktasına işaret etmiştir: sanat dallarının, dinin ve politikanın edebiyat ile ilişkilendirilmeleri meselesinin edebiyat ile ilgili olup olmadığı ve genel edebiyat bilimi bağlamında değerlendirilip değerlendirilemeyeceği meselesi. Ona göre ancak ulusal üstü bir düzlemde ve karşılaştırılarak irdelendiklerinde genel geçer bulgulara ulaşılabilir (Remak 1961:3). Bu hususta sınırın nerede olduğu Dyserinck için çok nettir:

“Eine Untersuchung etwa zum Verhältnis zwischen der französischen Literatur der Aufklärungsperiode und dem religiösen Leben der Zeit gehört eindeutig zur Erforschung der französischen Nationalliteratur; sie wird mit Mitteln der französischen Literaturgeschichtsschreibung durchgeführt und führt zu Erkenntnissen, die in erster Linie in diesem Bereich ihre Gültigkeit haben. Untersuchungen über das Verhältnis von Religion und aufklärerischer Literatur überhaupt bzw. von Religion und Literatur schlechthin können hingegen nur sinnvoll sein, wenn sie möglichst viele nationalliterarische Bereiche umfassen." (Dyserinck 1991: 157)

(Aydınlanma dönemindeki Fransız edebiyatı ile dönemin dini yaşantısı arasındaki ilişkiyi inceleyen bir araştırma kesin olarak Fransız ulusal edebiyatına aittir; Fransız edebiyat tarihi yazıcılığı araçlarıyla yürütülür ve birinci derecede bu alanda geçerliliğe sahip olan bulgulara yönlendirir. Buna karşılık genel olarak din ve aydınlanmacı edebiyat ilişkisi veya din ve edebiyat ilişkisi gibi araştırmalar ancak mümkün olduğu kadar çok milli edebiyat alanlarını kapsadığında anlamlı olabilir.)

Dyserinck burada Komparatistik çalışmalarının alan sınırlandırmasını veya sahanın ne kadar genişletilebileceğini ele almıştır. Genel edebiyat biliminin karakteristiği salt edebiyatın genel özelliği, kökeni, etkisi ve teorisi bağlamında ulusal üstü bir düzlemde belirlemeye çalışıldıktan sonra bu yan alanın Komparatisik düzleminde ne gibi imkânlar sunduğu akla gelmektedir. Evi Zemanek'e göre genel edebiyat bilimi, edebiyatın teorisini, 
metodolojik temellerini, üretimi ve alımlanmasıyla ilgili kuramsal unsurları ulusal edebiyatın ötesinde çalışma alanının merkezine yerleştirmektedir (Zemanek-Nebrig 2012: 13). Gürsel Aytaç'a göre "edebiyatın kuramlarını, tariĥ̂ gelişimini, çözümleme alımlama yöntemlerini, değerlendirme olgusunun dayandığı ilkeleri, yaratıcılık-üreticilik sürecini, ulusal sinırlar da aşarak inceleyen, belgelere dayandırarak araştıran bilim dal ise genel edebiyat bilimi olarak biliniyor" (Aytaç 2003: 9). René Wellek ve Austin Warren ise genel edebiyat teorisi araştırmalarının bütün edebiyatlarla ilintili olan kuramları kapsadığını belirtilmektedir. Onlara göre "Genel Edebiyat" kavramı, başlangıçta edebiyatın teori ve prensipleri için kullanılırdı. Fakat Paul Van Tieghem bu kavrama karşılaştırmalı edebiyata zıt olan bir anlam yüklemiştir. Wellek ve Warren'in Tieghem'den aktardıklarına göre, Karşılaştırmalı Edebiyat birden fazla edebiyatın karşılıklı ilişkilerini incelerken, Genel Edebiyat ulusal sınırları aşan edebi akımları ele alır (Wellek-Warren 1983: 59). Ancak Dyserinck'in tespitine göre, Wellek ve Warren'in bu tespitlerine son otuz yılda birçok ilave yapanlar olmuştur. Bunun neticesinde ona göre artık bir edebiyat yapıtının özerkliğinden bahsetmek oldukça güçtür. Komparatistik bütün arka planıla birlikte yazarı, eserden hareketle ve eserin kendisi dâhil olmak üzere okuyucu ve okur kitlesini çalışma alanına dâhil etmiş durumdadır. Edebiyat-Psikoloji ilişkisine dair merak ve sorgulamalar son yıllarda çok artmıştır. Bunun neticesinde önceden psikologlarca yürütülen bir eylemin edebiyat ile ilintilenebileceği fikri uyanmıştır. Bu, edebiyat ile toplum, düşünce tarihi ve diğer sanatlar ilişkisi için de geçerlidir. Edebiyatın ontolojisi de artık bu kapsamda ele alınmaktadır (Dyserinck1991: 159). Günümüzde çoğu bilim dalı için söz konusu olan disiplinlerarasılık elbette edebiyat için de geçerlidir. Bilimlerin ve buna bağlı olarak edebiyatın da değiştiği gerçeğini kabullenmekte geç kalmanın telafisi güç sakıncaları olabilir. Artık edebiyat bilimi varlığını sürdürebilmesi için adeta değişik sistemlerin eşzamanlı çalışmasına ayak uydurmak zorundadır. Batıdaki edebiyat çalışmalarına bakıldığında böyle bir tehlikenin edebiyat bilimi için geçerli olduğu söylenemez. Çünkü edebiyat çoklu kültürel sistemler içinde yerini çoktan almıştır. Bu hususta genel ve karşılaştırmalı edebiyat biliminin (Komparatistik) katkısı inkâr edilemez. Edebiyatın söz konusu çoklu sistem içinde kaybolma tehlikesini bertaraf etmek için yine en önemli yardımcı kuşkusuz Komparatistik yöntemi olacaktır.

Birbirlerinden ayrı alanlar olsalar da Karşılaştırmalı ve Genel Edebiyatlar birbirleriyle yoğunlaşmış ve zaman içinde birbirlerine bağımlı hale gelmişlerdir. Bundan dolayı Wellek ve Warren her ikisini de kapsayacak şekilde sadece edebiyat tabirinin kullanılmasının daha iyi olacağını düşünmektedirler. Onlara göre Karşılaştırmalı ve Genel Edebiyatlara göre kendi içine kapalı milli edebiyatlar olamaz; bu durum en azından Batı edebiyatı için düşünülemez:

"Hiç değilse Batı Edebiyatı bir bütün meydana getirir. Yunan ve Roma edebiyatları, Batı ortaçă̆ dünyası ile önemli modern edebiyatlar arasındaki bir devamlılıktan kimse şüphe edemez ve Doğu'dan gelen tesirlerin, Özellikle İncil'in tesirinin önemini küçümsemeden, bütün Avrupa'yı, Rusya'yı, Amerika Birleşik Devletleri'ni ve Latin-Amerika edebiyatların içine alan tam bir birliğin varlığı kabul edilmelidir." (Wellek-Warren 1983: 60)

Schlegel Kardeşler, Bouterwek, Sismondi ve Hallam tarafından da savunulan bu düşünce daha sonra artan milliyetçilik düşünceleri sebebiyle göz ardı edilerek milli edebiyat incelemeleri ön plana çıkmıştır. Fakat 20. yüzyılda genel edebiyat tarihi düşüncesi yeniden gündeme gelmiştir. Ernst Robert Curtius'un "Avrupa Edebiyatı ve Lâtin Ortaçağı" 
(Europäische Literatur und lateinisches Mittelalter) ile Erich Auerbach'ın "Mimesis" başlıklı kitapları buna örnek olarak gösterilebilir. Bu çalışmalar milliyetçilik düşüncesinden ödün vermeksizin ortaçağ Hıristiyanlığının Batı medeniyetinin bütünlüğünü meydana getirdiğini gösterirler (Wellek-Warren 1983: 61). Curtius ve Auerbach gibi Wellek ve Warren de edebiyat tarihinin bütünlüğünü savunmuşlar ve bununla ilgili bazı ilkeleri öne sürmüşlerdir:

"Edebiyat tarihi bir bütün olarak, milliyetçilik ölçüsünün ötesinde tekrar yazılmalıdır. Bu anlamda mukayeseli edebiyat incelemesi yapacak olanlarm yabanci dilleri iyi bilmeleri gerekir. Bu çeşit inceleme için olaylara daha geniş açıdan bakmak, mahallî ve dar fikirleri bastırmak lazımdır ki, bu da kolay bir iş değildir. Sanat ve insanlık nasıl bir bütünse edebiyat da öyledir."(Wellek-Warren 1983: 61)

Wellek ve Warren bu düşünceyi ileri sürerken öncelikle kastettikleri Batı Avrupa uluslarının ortaçağ Hıristiyanlığ1 ekseninde meydana gelmiş olan kültür paralellikleri bağlamında bütüncül bir edebiyat çerçevesinde birleşmeleridir. Genel edebiyat anlayışlarını bu şekilde dile getirmişlerdir.

\section{KARŞILAŞTIRMALI EDEBIYYAT BİLIMMI}

Karşılaştırmalı edebiyat, kavram olarak bugünkü haline gelene kadar birçok evreden geçmiştir. Matthew Arnold 1848'de Amperé'in “Mukayeseli Tarih" tabirini İngilizceye çevirerek bu kavramı ilk defa İngilizcede kullanmıştır. Georges Cuvier (1769-1832) ise aynı anlamdaki "Mukayeseli Anatomi" (Anatomie Compareé) kavramını tercih etmiştir. Ancak Fransızlar daha çok Abel-François Villemain'in (1791-1870) "Karşılaştırmalı Edebiyat" (Litterature Compareé) terimini öne çıkarmışlardır. Almanlar "Karşılaştırmalı Edebiyat Tarihi" (Vergleichende Literaturgeschichte) kavramını geliştirmişlerdir. Ancak Rene Wellek ve Austin Warren'in de belirttikleri gibi, bu kavramlar yeterince açılayıcı görülmemiştir. Çünkü karşılaştırma, bütün bilim dallarında kullanılan bir yöntemdir ve edebî incelemenin usullerini açıklamak için yeterli değildir (Wellek-Warren 1983: 55).

Genel edebiyat bilimi, edebiyatın teorisini, metodolojik temellerini, üretimi ve alımlanmasıyla ilgili kuramsal unsurları ulusal edebiyatların ötesinde çalışma alanının merkezine yerleştirirken, karşılaştırmalı edebiyat bilimi ulusal edebiyatların, edebi akımların, devirlerin ve eser çevirilerinin karşılaştııılmasıyla uğraşır. Ortak konu ve motiflerin tespit edilmesi ile onların gelişimlerini incelemek de karşılaştırmalı edebiyat biliminin işidir. Bu bağlamda kültürlerarası alışveriş ile bir toplum içindeki çok kültürlülüğe odaklanmak kaçınılmaz bir durumdur. Ulusal üstü bir düzlemde kültürel ilişkiler ve çok kültürlülük ile uğraşan karşılaştırmalı edebiyat bilimi aynı zamanda edebiyatın diğer sanatlarla, başka medyalarla ve edebiyat biliminin diğer disiplinlerle olan ilişkisini karşılaştırarak inceler (Zemanek-Nebrig 2012: 13). Bu tespitler sonucunda genel edebiyat bilimi ile karşılaştırmalı edebiyat biliminin sınırları büyük ölçüde belirlenmiş durumdadır. Her ikisinin de ayrı birer disiplin olduğunu söylemek yanlış olmayacaktır. Fakat ayrı alanlar olmalarına rağmen çoğunlukla birlikte anılmaktadırlar. Bunun sebebi her iki alanın birbirlerine olan bağımlılıklarına ve ortak hedeflerine bakıldığında görülebilir.

Edebiyat tarihinde akımlar, yazarlar, eserler arasında yapılan karşılaştırmalar alanla ilgili önemli bir uğraşı teşkil eder. Fakat ülke edebiyatları arasında yapılan karşılaştırmalar sadece benzerlik ve farklılıkları belirlemekle kalmayıp bir milletin edebi gelişmişliğini ortaya koyması bakımından da önemlidir. F. C. Green'in 18. yüzyıl Fransız ve İngiliz edebiyatlarını 
karşılaştırdığı "Minnuet" başlıklı çalışması buna örnek verilebilir (Green 1939; WellekWarren 1983: 56; Johan 2004: 48).

Toplumların ve milletlerin birbirlerini tanımalarında edebiyatın büyük öneme sahip olduğunu belirten Turan Karataş, edebi etkileşim aracilığıyla milletlerin başka ülke edebiyatlarında kendine yer edindiğini dile getirerek Karşılaştırmalı Edebiyatın etkileşimle ortaya çıkan benzerlik ve farklılıkları ortaya koymak için yapılan çalışmaları kapsadığını belirtmektedir. Günümüzde küreselleşmeye bağlı olarak geniş bir sahaya yayılmış olan karşılaştırmalı edebiyat çalışmalarının hız kazandığına değinen araştırmacının bu alanın tanımını yaparken tesir konusunu merkeze yerleştirdiği görülmektedir: "Aralarında tarihin belli döneminde yakınlık, komşuluk ilişkileri; kültür alış-verisi bulunan milletlerin edebiyatlar üzerinde "mukayese" esasına uygun olarak yapılan araştırmalar, incelemeler, çalışmalar için kullanilan bir terimdir" (Karataş 2001: 239). Oysa tesir, etki ve etkilenme eylemlerinde ipuçlarını takip etmek, kimin alıcı kimin verici olduğunu araştırmak, karşılaştırmalı edebiyat çalışmalarının etkin olduğu sadece bir alandır ve bu sahada yapılan çalışmalar için amaçtan öte bir başlangıcı teşkil eder. Bu noktada tesir konusunun dışında Komparatistik'in etkin olduğu diğer alanlardan bazılarını belirtmekte fayda vardır. İnsanlık tarihi boyunca yaratıcılık ürünlerinde var olan ortak konu ve motif çalışmaları, tarihsel perspektif doğrultusunda edebi türlerin gelişim çizgilerini araştırmak, imge çalışmaları, alımlama estetiği, gelişen teknoloji karşısında edebiyatın tutumu/konumu ve edebiyatın medyalar arası ilişkisi gibi birçok çalışma sahası da Karşılaştırmalı edebiyatın alanına dâhildir (Aytaç 2003: 74-92).

Karşılaştırmalı edebiyat uygulamada ilk olarak sözlü edebiyatın yayılımını ve nasıl yüksek edebiyat haline geldiğini incelemeyle başlamıştır. Bu tür incelemeler daha çok folklor sahasına dâhil edilebilir. Sözlü edebiyat yazılı edebiyatı geniş anlamda etkilemiştir. Halk edebiyatı toplumsal kaynaklıdır ve önemli temalar bu alan orijinlidir. Bundan dolayı edebi türlerin oluşum ve gelişimlerini incelemek ve anlamak için edebiyat bilimcilerinin sözlü edebiyata yönelmeleri elzemdir. Ancak "'mukayeseli edebiyat' tabiri, sözlü edebiyat incelemesini belirtmek için yeterli bir tabir değildir" (Wellek-Warren 1983: 57). Karşılaştırmalı edebiyatın bir başka fonksiyonu ise iki veya daha fazla edebiyat arasındaki ilişkileri incelemektir. Kavramın bu anlamda kullanılması Fernand Baldensberger başkanlığında toplanan Fransız Ekolü'ne dayanır. Bu ekol özellikle Goethe'nin Fransa ve İngiltere'deki, Schiller'in Fransa' daki etkileri üzerine yoğunlaşmıştır. Fransız ekolünün geliştirdiği yöntem bir yazarın belli bir dönemdeki konumu, algılanışı ve yayılımı üzerine kuruludur. Böylelikle Batı Avrupa edebiyatları arasında sıkı bir ilişki olduğu kanıtlanmış ve yabancı edebiyatlar hakkında geniş bilgi elde edilmiştir. Karşılaştırmalı edebiyata isnat edilen üçüncü görüş ise, onun "Dünya Edebiyatı" $n 1$, "Genel Edebiyat" 1 ve "Evrensel Edebiyat" 1 kapsamasidır. Böylelikle geniş anlamda bir edebiyat incelemesi statüsüne konumlandırılmaktadır (WellekWarren 1983: 57-58).

Genel edebiyat bilimi teori üretiminde bulunurken karşılaştırmalı analizlerden sonuçlar çıkarır. Böylelikle karşılaştırmalı edebiyat bilimi genel teori oluşumunu teşvik eder; bunu yaparken genel teorik koşullara dayanır. Her ikisinin de ortak amacı genel bir teori oluşumunu ve ulusal üstü bir sistemleşmeyi sağlayarak bu çizgide üretilmiş bir edebiyat tarihi yazımını mümkün kılmaktır (Zemanek-Nebrig 2012: 13). Bu iki disiplinin birlikte çalıştıkları alana ise Komparatistik denilmektedir. Komparatistiğin temel öğesi olarak genel ve karşılaştırmalı edebiyat bilimlerinin bağlantılanmaları fikri yeni değildir. Dyserinck buna örnek olarak toplum için edebiyat ve sanat dersleri veren Ampér'i örnek göstermiştir.

SEFAD, 2018 (39): 1-26 
Ampér karşılaştırmalı bir bakış açısıyla edebiyatları genel bir felsefede birleştirmeyi ve ulusal üstü bir estetikle buluşturmayı amaçlamıştır. Hatta Ampér'in görüşüne göre 'güzelliğin yeni kuralları' ancak karşılaştırma ile tespit edilebilir (Dyserinck 1991: 155). Her ulusal filolojide olduğu gibi bütün sosyal ve fen bilimlerinde ister istemez karşılaştırılır. Karşılaştırma mukayese edilen olayların özelliğini tespit etmek, benzerlik ve farklılıklarını belirlemek amacıyla yapılır. Bunu Komparatistik'e uyarladığımızda, farklı kültürlere ait tarihsel veya sistematik olarak birbirleriyle ilişkilendirilebilecek olan edebiyat eserleri mukayese edilir. Buna özerk olaylardan ayrı olarak dönem, akım ve sanat karşılaştırmaları da dâhil edilebilir. Ancak uygulama olarak karşılaştırma Komparatistik alanının kurumsallaşmasından çok daha önce yerleşmiştir. Komparatistik her ne kadar yeni bir alan olsa da onun uğraştığı birçok alanla antik dönemden beri ilgilenildiği bilinmektedir. Bu ilgi Komparatistik alanında bir disiplin haline gelmiştir diyebiliriz. Komparatistik'in yöntemi analiz, deneysel istatistikler, metin yorumlaması ve değişik metotların tarihsel bağlamda yeniden yapılanması gibi birçok hususun bileşimlerinden meydana gelir. Ancak Komparatistik'in yöntemini diğerlerinden asıl ayıran karşılaştırma merkezli bir eylem olmasıdır. Karşılaştırma adeta yönlendirici bir ana izlek niteliğindedir ve dünya edebiyatının beslendiği, varlığını borçlu olduğu temel husustur. Ayrıca estetik değer yargılarını geliştirme fonksiyonuna sahip olduğu da bir gerçektir (Zemanek-Nebrig 2012: 1819).

Angelika Hoffman, Fransız edebiyat bilimci ve komparatist Paul Van Tieghem'in (1871-1948) edebiyat tarihçiliği için genel ve karşılaştırmalı edebiyat bilimlerinin sentezini koşul olarak gördüğünü belirtmiştir. Ona göre Tieghem genel edebiyattan ulusal sinırları aşan akımları ve edebi oluşumları, karşılaştırmalı edebiyattan ise iki veya daha fazla edebiyatın ilişkisini anlar. Bu tespitten genel edebiyatın da karşılaştırma eğilimli olduğu anlaşılmaktadır. Amerika ve Almanya'da genel edebiyattan ayrıca tipoloji de anlaşılmaktadır (Hoffmann 2000: 13). Avusturyalı edebiyat bilimcisi Peter Václav Zima'ya göre karşılaştırmalı edebiyat bilimcisinin edebiyat dışı alanlarla da ilgili olması çok doğaldır. Çünkü ona göre edebiyat ve müzik, edebiyat ve film veya resim sanatı iç içe geçmiş durumdadır. Ancak Zima'ya göre karşılaştırmalı edebiyat öncelikle bir edebiyat bilimidir. Fakat önemli olan karşılaştırmalı edebiyat biliminin iki veya daha fazla edebiyatı, edebiyat akımlarını veya dilsel olmayan metinleri (resim, film vb.) inceleyip incelemediği değildir. Dikkat edilmesi gereken asıl mesele hangi teorik ve metodolojik araçlarla çalıştığıdır. Bu perspektiften bakıldığında genel edebiyat bilimi karşılaştırmalı edebiyat biliminin teorik ve metodolojik repertuarın meydana getirmektedir (Zima1992: 6-7). Bu durumda karşılaştırmalı edebiyat bilimi, genel edebiyat bilimi çerçevesinde incelemesini nasıl yapacağını belirler. Dyserinck'in bu konuyla ilgili düşüncesi Zima'nın görüşünü bir üst aşamaya taşır niteliktedir. Dyserinck "Komparatistik" başlıklı çalışmasında ulusal üstü yürütüldüğü ve karşılaştırmalı edebiyat bilimi için vazgeçilmez olduğu için "Genel Edebiyat Bilimi" yerine "Karşılaştırmalı Edebiyat Teorisi ve Metodolojisi" (Vergleichende Literaturtheorie und -Methodologie) kavramını kullanmanın daha doğru olacağını önerdikten sonra Hollanda'da Genel Edebiyat Bilimi ile karşılaştırmal ulusal üstü edebiyat anlayışını kastedenlerin olduğunu ifade etmiştir. Ancak daha sonra onlarca yıldan beri uluslararası platformda Littérature Comparée, Comparative Literature vs. veya alanı çok net olarak ifade eden Comparatisme ve Komparatistik kavramlarının yerleştikten sonra ulusal üstü edebiyatla ilgili alanların tamamını farklı bir kavramla özdeşleştirmeye çalışmanın makul bir davranış olmayacağını belirtmiştir (Dyserinck 1991:158). Dyserinck kavram ile ilgili bu 
düşünceleri dile getirdikten sonra ulusal üstü edebiyat teorisi araştırmalarının karşılaştırmalı uygulamaları nerelerde kullanabileceğine dair tespitlerde bulunmuştur. Bunları maddeler halinde şöyle özetlemek mümkün:

1) Mevcut genel edebiyat teorilerini geliştirmek ve ortak prensiplere indirgeyebilmek.

2) Ortak edebiyat teorisi prensiplerinin geçerliliğini çok uluslu edebiyat tarihinden somut örnekler vererek karşılaştırmalı metotla kontrol etmek.

3) Bir ülke edebiyatı temelli inceleme ve teori araştırmalarıyla elde edilen bulguları karşı karşıya getirerek ilişkilendirmek koşuluyla genel edebiyat için elzem olan tezlerin uluslar arası uygulanabilirliğini denetlemek. Bunun için çok kültürlü alana ait olan kıyaslanabilir verileri karşılaştırmalı edebiyat tarihi alanına dâhil etmek (Dyserinck 1991:160).

Goethe 16 Aralık 1828 tarihinde, 79 yaşında iken Eckermann ile yaptığı bir söyleşide başka medeniyetlere ve yazarlara çok şey borçlu olduğunu şöyle dile getirmiştir. Goethe'nin bu ifadeleri aynı zamanda karşılaştırmalı edebiyatın genel ilkelerini yansıtır niteliktedir:

"Wir bringen wohl Fähigkeiten mit, aber unsere Entwickelung verdanken wir tausend Einwirkungen einer großen Welt, aus der wir uns aneignen, was wir können und was uns gemäß ist. Ich verdanke den Griechen und Franzosen viel, ich bin Shakespeare, Sterne und Goldsmith Unendliches schuldig geworden. Allein damit sind die Quellen meiner Kultur nicht nachgewiesen; es würde ins Grenzenlose gehen und wäre auch nicht nötig. Die Hauptsache ist, daß man eine Seele habe, die das Wahre liebt und die es aufnimmt, wo sie es findet."(Eckerman 2016)

(Bizler elbette becerilerimizi beraberimizde getiririz, fakat gelişimimizi yapabildiğimiz ve bize uygun olana uyum sağladığımız büyük bir dünyanın etkisine borçluyuz. Yunanlara ve Fransızlara çok müteşekkirim, Shakespeare'e, Sterne'ye ve Goldsmith'e sonsuz derecede borçluyum. Fakat kültürümün kaynakları sadece bunlarla gösterilemez; sınırsıza giderdi ve gerekli değil. Önemli olan insanın doğruyu seven ve onu nerede bulursa kabul eden bir ruha sahip olmasıdır.)

Goethe'nin edebiyat ve edebiyat dışı faktörlere bağlılı̆̆ını ifade eden itiraf niteliğindeki bu açıklamaları Karşılaştırmalı Edebiyat'ın merkezi çalışma alanıyla temelde örtüşmektedir. Bunlardan birisi metinlerin ilişki ağını diyakronik ve senkronik düzlemde araştıran metinlerarasılık araştırmalarıdır. Metinlerarası referans araştırmalarıyla etki araştırmaları yeni bir metin anlayışı temelinde yürütülerek konu, motif, biçim ve türlerin gelişimi tarihsel ve sistematik bağlarla aydınlatılmaya çalışılır. Bireysel filolojiler metinleri tarihsel öncüleriyle veya aynı zamanda meydana gelmiş metinlerle ilişkilendirmeye çalışırken Karşılaştırmalı Edebiyat metinleri özellikle farklı kültürlerdeki metinlerle ilintilemeyi amaçlar. Uluslararası ilişkilerin yapılandırılmasındaki hedef, bir eseri daha geniş, ulusal sınırların ötesinde ve böylelikle daha "mantıklı" bir bağlam içinde görebilmektir (Zemanek-Nebrig 2012: 10). Goethe'nin yukarıda alıntılanan cümlelerinde de neredeyse Komparatistik temelinde olduğu gibi edebiyat kültürle eşdeğer görülmektedir. Kültürbilimsel sorgulama elbette ki sadece Komparatistik alanıla ilintili değildir. Ancak Komparatistik için vazgeçilmez bir husustur. 


\section{ULUSAL EDEBIYYAT VE KARŞILAŞTIRMALI ÇALIŞMALAR}

Hiçbir ulusal edebiyat, başka ulusların edebiyatına bakmaksızın, sadece kendinden meydana gelmemiştir. Her filolog metinlerin konu, motif, biçim ve oluşum serüvenleri bakımından izole edilmiş olarak incelenmelerinin mümkün olmayacağını bilir. Barışçıl bir amaç güderek farklı olana kapılarını açmak ayrıcalıklı olmanın bir gereğidir. Nasıl sadece karşılaştırmalı edebiyat çerçevesinde anlaşılması mümkün olan hususlar var ise sadece veya birinci derecede ulusal edebiyatlar bağlamında açılanabilecek meseleler de vardır. $\mathrm{Bu}$ durumda ulusal edebiyatlardan hareketle genel olana ulaşılır ve ulusal edebiyatın ayrıcalığı da karşılaştırma neticesinde belirlenebilir.

Sosyolojinin, ekonomi ve siyaset bilimlerinin araştırma konusu olan uluslar var olduğu sürece edebiyatı uluslararası perspektiften olduğu gibi ulusal bir bakış açısıyla değerlendirmek her zaman önemini koruyacaktır (Zima 2011: 13-14). Diğer taraftan ulusal üstü çalışma neticesinde ulusal edebiyat için önem arz eden birçok husus tespit edilebilir. Sadece ulusal üstü çalışan bir edebiyat bilimi edebiyatın yapısı, edebiyat ve toplum ilişkisi, edebiyat ile diğer sanatların ilişkisi gibi sistematik-teorik meseleleri çözmeye yetkin olabilir. Sadece ulusal üstü çalışan bir edebiyat ile edebiyat biliminin uluslararası gelişimi için farklı dil alanlarından kaynaklı değişik metotların sistemli ve tarihsel süreç bağlamında mantıklı bir şekilde algılanıp analiz edilmesi mümkün olabilir. Hugo Dyserinck'e göre bu tür çalışmaların ulusal edebiyatlar tarafından da yürütülebileceği düşüncesi anlamsızdır. Eğer sadece tek bir edebiyattan hareketle genel bir edebiyat teorisi geliştirmeye çalışılırsa, bunun birçok bilinen durumda olduğu gibi başarısızlıkla sonuçlanması beklenmelidir. Dyserinck bu durumu şöyle izah etmiştir: "Die behandelten Erscheinungen in einer Literatur A können in ihrer theoretischen Tragweiten und einmal grundverschieden sein von ähnlichbezeichneten oder ähnlich gelagerten Erscheinungen in eine rLiteratur B" (Dyserinck 1991: 152). (A edebiyatında ele alınan görüngüler benzer olarak ifade edilen veya benzer yapılanmaya sahip olan $B$ edebiyatından kuramsal kapsam bakımından temelde çok farklı olabilir). Dyserinck bir A edebiyatındaki bazı hususların B edebiyatına kıyasla benzer olmasına karşılık teorik olarak temel farklılıklara sahip olabileceğini belirttikten sonra Komparatistik'in ve ulusal edebiyatların bağımsızlıklarından bahsetmiştir. Ona göre özel ve ulusal üstü edebiyat bilimi Komparatistik kapsamında ele alınırken ulusal edebiyatların özerkliği buna engel değildir. Bu durum Dyserinck'e göre daha ziyade yetki dağılımı ile ilgilidir (Dyserinck 1991: 161). Komparatistik ulusal filolojilerin bireysel çalışmalarının bittiği yerde başlar ve onların sunduğu sonuçları farklı bir anlamda araştırma alanı olarak ele alır. Bu eylem ulusal edebiyatların özerkliğine bir saldırı olarak algılanmamalıdır.

Bütün edebi metinlerin diğer metinlerle, özellikle de yabancı metinlerle, karmaşık bir ilişki içinde olduğunu çok uluslu durumlarda görmekteyiz. Evi Zemanek bu durumu bir örnekle açıklamıştır: İtalyan şair Francesco Petrarca'nın (1304-1374) öncülüğünü yaptığı ve Avrupa'nın tamamını etkisi altına alan bir aşk şiiri üslup hareketi olan Petrarkizm, örnek olarak verilebilir. Yaklaşık 1348 olarak tarihlenen "Canzoniere" başlıklı şiir külliyatı yüzlerce yıl boyunca sıklıkla referans olarak kullanılmıştır (Zemanek-Nebrig 2012: 9; Petrarca 2016). Hümanist düşüncenin öncülerinden olan İtalyan şair Petrarca sone biçiminde eserler üretmiş, kendine özgü alegori, tını ve söz oyunları gibi araçlarla aşığın ruh halini şiirlerine yansıtarak kendi zamanını aşan bir etkiye sebep olmuştur (Müller 1996: 323). 20. Yüzyıla kadar devam eden popülerliğinin verdiği ilhamı zaman ve mekâna bağlı olmamasından kaynaklanmaktadır. Sadece Petrarca'nın eserleri değil, ona öykünen birçok yazarın eseri de çevrilmiş ve taklit edilmiştir. Bu geleneğe Shakespeare gibi birçok ünlü şair de dâhildir. 
Zemanek ve Nebrig'in belirttiğine göre İngiliz şiir tarihinin zirvelerinden biri olan onun soneleri ancak Petrarkizm bağlamında anlaşılabilir (Zemanek-Nebrig 2012: 9). Fansız Pléade'leri 16. yüzyılda petrarkist şiirlerden yararlanmışlardır. Alman Barok akımında Christian Hoffman von Hoffmannswaldau (1616-1679)'da da Petrarkizmin alımlanması görülmektedir. Deha düşüncesine odaklı olan Fırtına ve Coşku (Sturm und Drang) dönemindeki Goethe şiirleri de bu geleneği yansıtmaktadır (Zemanek-Nebrig 2012: 9). Bu örneklerden de anlaşılabileceği gibi edebiyatta etkileme ve etkilenme vardır. Bir ulusun edebiyatı diğer edebiyatları etkileyebilmektedir ve değişik varyasyonlarla farklı ülke edebiyatlarında benzer durumla da karşılaşılabilmektedir. Bu bağlamda metinler arası ilişkiler devreye girmektedir ve çözümlemek için birden fazla yazara, esere, ulusa veya dile yönelmek gerekli olabilir. Bu yüzden genel bağlamda bir teori belirlemesinde bulunabilmek için genellikle ulusal sınırları aşmak kaçınılmazdır. Ulusal edebiyatların gerçek nitelikleri ve kapsamları da ancak bu şekilde anlaşılabilir.

Komparatistik ve ulusal filolojiler edebiyat teorisi bağlamında edebiyat tarihinden farklı bir konuma sahiptirler. Karşılaştırmalı edebiyat tarihi ulusal filolojiler için önemli mevzuları dikkate alma sınırlılı̆̆ı olmaksızın kendi metoduyla çalışma ve ulusal filolojilerden farklı sonuçlara götürme olanağı sunar; karşılaştırmalı edebiyat teorisi ve ulusal filolojilerle kopmaz bir bağ içindedir. Bu bağlamda Komparatistik edebiyat teorisi alanında ulusal filoloji araştırmalarına katkıda bulunur. Komparatistik metot olarak ancak çok uluslu edebiyat teorisi araştırmalarında yöntem olarak gereksinim duyulduğunda harekete geçer.

Küreselleşme sonucu birçok alana nüksetmiş olan çok kültürlülük Komparatistik için uygun bir araştırma alanı oluşturmaktadır ve özgün sonuçlar ortaya çıkarmaktadır. Buna bağlı olarak ulusal filolojiler de ister istemez genel kültürel değişimlere, disiplinler arası sınırların esnekleşmesine ve artan karşılaştırmalı çalışmalara ayak uydurmak zorunda kalmışlardır. Komparatistik çalışmalar artık olağan bir hal almıştır ve çoğu zaman bireysel filolojilere tercih edilmektedir. Batıya bakıldığında Romanistik, Slavistik, Amerikanistik, hatta Orientalistik gibi birçok alanın birleşmesi ve Komparatistik bir alana dönüşmesi görülmektedir (Zemanek-Nebrig 2012: 14). Zemanek ve Nebrik Batı'daki Komparatistik'in durumunu bu minvalde anlatmaktadır. Fakat bu durum çoğu zaman tartışmalı bir mesele olarak güncelliğini muhafaza etmektedir.

Edebiyat ve toplum sorusu irdelendiğinde araştırmacı kesin olarak edebiyat teorisi alanında dolaşmaktadır. Edebiyat-Biyografi, Edebiyat-Din, Edebiyat-Düşünce Tarihi veya Edebiyat-Müzik ilişkileri irdelendiğinde de aynı durum söz konusudur. Aynı durum edebiyat eserinin ontolojisi, içindeki eğretileme ve semboller söz konusu olduğunda da geçerlidir. Bu tür sorularda asıl amaç edebiyatın mantalitesini, kaynağını ve etkisini belirlemektir. Ancak sosyolojinin, psikolojinin veya sanat tarihi yöntemlerinin edebiyatta ne derece uygulama bulabileceği sorusu sorulduğunda, o zaman kesin olarak araştırmacı yöntembilim alanına dâhil olmuş demektir (Dyserinck 1991: 162-163). Uygulamada edebiyat teorisi ile metodoloji çoğu zaman birbirine yakınlaşmakta, hatta kesişmektedir. Örneğin; bir edebiyat eserinin ortaya çıkma sürecini bilinçaltı bağlamında araştıran bir edebiyat teorisyeni ister istemez psikoloji ve onun yan alanlarıyla da ilgilenmek zorundadır. Her ne kadar böyle olsa da teori ve metodoloji edebiyat bilimi içinde birbirinden farklı amaçları olan ayrı disiplinlerdir. Genel edebiyat biliminde teori ve metot bağlamındaki bu sınırlama çok önemli olmamasına karşıllık ulusal filolojilerde Komparatistik ile ulusal filoloji ilişkisini açıklamak bağlamında önemlidir. Komparatistik-Ulusal Filoloji ayırımını ancak Genel 
Edebiyat Bilimi, Karşılaştırmalı Yöntembilim bağlamında belirleyebilir. Karşılaştırmalı Metot Bilgisi (vergleichende Methodenlehre) ulusal filoloji uygulamalarına küçümsenmeyecek teorik bilgi aktarımında bulunabilir. Karşılaştırmalı yöntembilim özünde var olan uluslararası edebiyat bilimi bağlamında metot gelişimini kapsamaktadır. Gerektiğinde karşılaştırmalı bir çalışma tarzına sahip olan Genel Edebiyat Bilimine karşılaştırmalı yöntembilim kapsamında yararlı olabilecek ve ulusal filolojilere katkı sağlayabilecek bir vazife biçilebilir. Bu durum özellikle uluslararası yönlendirilmiş olan bireysel filoloji derslerinde faydalı ve etkili olabilir. Dyserinck bununla ilgili şunları dile getirmiştir:

"Während die vergleichende Literaturtheorie dafür führt, den Reichtum von Sein und Funktion der Literatur aufzuzeigen, bietet die vergleichende Methodenlehre Einblicke in die Vielseitigkeit der literaturwissenschaftlichen Verfahrungsweisen selbst. Und gerade durch ihre spezifisch komparatistische (d.h. nicht nationalliterarisch gebundene) Perspektive wird sie die multinationalen Entwicklungen von literaturwissenschaftlichen Methoden und Methodendiskussionen in den Griff bekommen und-mehr als jede Nationalphilologie- über Möglichkeit verfügen, Hintergründe, Wirken und Tragweite der Literaturwissenschaft selbst zu erfassen.[...]Auch sollte sie sich darüber im klaren sein, daß eine an den Universitäten deutlich präsente Komparatistik auch dazu beitragen kann, den Nationalphilologien zu einem deutlicheren Selbstverständnis zu verhelfen; d.h. ihnen insbesondere ihre Grenzen und damit ihre wahren Intensivierungsmöglichkeiten zu verdeutlichen."(Dyserinck 1991: 164, 168)

(Karşılaştırmalı edebiyat teorisi varlık ve edebiyatın zenginlik fonksiyonunu göstermeyi amaçlarken, karşılaştırmalı metot öğretisi edebiyat biliminin çalışma tarzının çok yönlülüğüne dair bir izlenim edinmeye dair bir imkân sunar. Özellikle Komparatistik'inspesifik perspektifi sayesinde ulusal edebiyata bağlı olmadan edebiyat biliminin metodunun ve metot tartışmalarının çok uluslu gelişimleri kavramak ulusal filolojilerin mümkün kılamayacağı kadar edebiyat biliminin imkanları sunulur, sebepleri, etkileri ve yaygınlığı belirlenmeye çalışılır. [...] Üniversitelerdeki Komparatistik bölümlerinin ulusal filolojilerin anlaşılmalarına bariz bir şekilde katkı sağladıkları da net bir şekilde anlaşılması gerekir; bu onların özellikle alan ve böylece asıl yoğunlaşma olanaklarının kesinleşmesi anlamına gelmektedir.)

Komparatistik çalışmalarında konunun işlenişi ve yöntem bağlamında ulusal filolojiler hiçbir zaman göz ardı edilmemelidir. Bu durum aynı zamanda Komparatistik araştırma sonuçlarının genel anlamdaki edebiyat öğretimi için faydacı amaçlar ortaya koymasına sebep olmaktadır:

Komparatistiğin elde ettiği sonuçlardan belki de geleneksel filoloji alanından daha çok düşünce tarihi, kültür sosyolojisi, edebiyat antropolojisi, azınlık psikolojisi ve siyaset bilimi gibi değişik bilim dalları için önemli bilgiler elde edilebilir (Dyserinck 1991: 173).

Teknolojinin gelişmesi ve yayın faaliyetlerinin çokluğu karşısında okuyucuların ve araştırmacıların maruz kaldıkları durum onların işini zorlaştırmaktadır. Her şeyi okuyarak bir izlenim uyandırma çabası, bu enginlik karşısında okurun yolunu çoğu zaman kaybetmesine sebep olmaktadır. Özellikle günümüzdeki yayın deryası bağlamında uygulama söz konusu olduğunda Komparatistik ile uğraşmanın kolay olmadığı anlaşılmaktadır. Hoffamann'ın da belirttiği gibi Bir karşılaştırmalı edebiyat bilimcinin neleri okumuş olması gerektiği, neleri bilmesi gerektiği ve neleri yapabilmesi gerektiği gibi basit 
soruların cevabını verebilmek kolay değildir; bu tür sorularla faydacı çözüm bulma çabaları durumu daha da zorlaştırmaktadır (Hoffmann 2000: 10). Ancak Komparatistik ile uğraşmayı zorlaştıran sadece yayın faaliyetlerinin çokluğu değildir. Uğraşılan edebiyatın dilini ve tarihini bilmek karşılaştırmalı edebiyat bilimcisi için ön şarttır ve temel donanım olarak kabul edilmektedir. Tür araştırmaları yapan araştırmacı türlerin tarih içindeki değişimine ve belli bir edebi türle özdeşleşmiş olan yazarların durumuna vakıf olmalıdır. Bu konularla ilgili olarak daha önce yapılmış mevcut tespitler bir karşılaştırmacı için hiçbir zaman malum bir mesele olarak kabul edilmemelidir. Buna karşıllk sadece tek bir ulusal edebiyatla uğraşmak daha rahat bir eylemdir. Çünkü sadece bir tane dil ile yüzleşmek veya tarihsel bağları olan dillerle uğraşmak yeterlidir. Fakat bazen tek bir eser de çok kültürlü veya uluslar arası bir düzlem meydana getirebilir. Böyle bir durum da Komparatistiğin ilgi alanındadır. Çünkü Komparatistik dillerin, kültürlerin, ulusların, bilimlerin ve sanatların kesişme alanlarında hareket eder. Angelika Hoffmann'a göre Komparatistik edebiyatın her türlü icrasını, dil ve ulus sınırlarını, sanat ve bilim dallarının akademik belirlenmelerini kapsamaktadır. Ona göre bu belirlenme yapılırken çoğu zaman sınırlar zorlanır ve diğer filolojilerin bittiği veya sınıra dayandığı yerde Komparatistik başlar. Hoffmann'a göre yabancı dilde yürütülen bir filoloji başka bir ülkede kendini evinde hissederken Komparatistik "dünya vatandaşı" gibidir ve edebiyatın olduğu her yer evi gibidir. Bazen bu sınır tanımazlık araştırmacıyı ütopik bir düzleme sürükleyebilir. Kendini her yerde evinde hissetme durumu araştırmacıyı hiçbir yerde olmama duygusuna kaptırabilir (Hoffmann 2000: 11-12).

Özellikle tek bir ulusun edebiyatına yoğunlaşmış olan klasik filoloji mensuplarının Komparatistiğe karşı yönelttikleri en yaygın eleştiri, bir eserin karşılaştırıldığında itibarının zedelendiğidir. Bu durum aslında özgün bir eserin çok kültürlü bir sistem içine dâhil edilmesiyle; niteliğinin ve karakteristik özelliğinin yok olduğuna dair bir endişeyi yansıtmaktadır. Oysa bu bir yanılgıdır. Çünkü bir eserin özgünlüğü ancak diğerleriyle irtibat kurulduğunda anlaşılır. İlişkilendirilen diğer eserler farklı dil ve kültür gruplarına ait ise eserin özgünlüğü uluslararası bir platforma taşınmış olur ki böylece itibarı daha da artabilir. Yani kısacası özgün olma durumu ancak karşılaştırılarak anlaşılabilir veya savunulabilir. İmagoloji çalışmalarında bunu ispatlayan birçok veri mevcuttur. Hoffmann'ın dikkat çektiği başka bir mesele vardır ki artık ulusal filolojiler ile Komparatistik çatışmasının sona erdirilerek asıl başka bir tehlikeye topyekûn yönelmeyi gerektirmektedir. Ona göre detaycı bir hassasiyetle edebiyat eserlerini incelemek artık olağan bir durum olmaktan çıkmıştır. Çünkü bu alan artık medyayla, özellikle de görsel medyayla rekabet etmek zorundadır (Hoffmann 2000: 15). İçinde bulunduğumuz yüzyıldaki dil ve edebiyat araştırmalarının yapısına baktığımızda, özellikle Batıdaki gelişmelerde filoloji alanının bir çözülme sürecine girdiği ve kültür araştırmalarına (Cultural Studies) meylettiği görülmektedir. Bunun böyle olmasında Komparatistiğin payı büyüktür. Çünkü Komparatistik salt edebiyatı kendi başına yeterli görmemektedir ve sürekli uluslararası bir düzlemde aynı içeriğin farklı dillerdeki (Polyglotte) aktarımıyla ilgilenir; bu esnada diğer sanat ve bilimlerle sürekli temas halindedir. Ancak karşılaştırmalı edebiyat biliminin bu açılımının diğer kültürel alanlar ve disiplinler tarafından olumlu karşılandığı ve görmezden gelindiği söylenemez. Oysa dünyanın teknoloji ve iletişim ağı içinde nitelik kaybına uğramamak için ulusal filolojiler gibi klasik yöntemlere bağlı olan alanlara da Komparatistik ufuk açıcı aktarımlarda bulunabilir. Komparatistik her ne kadar kültürler, disiplinler ve medyalar arası bir niteliğe sahip olsa da her zaman edebiyat bilimi ekseninde 
konumlanmıştır. Hoffmann bununla ilgili düşüncesini şöyle kaleme almıştır: "das sich vertiefen in Texte fordert konzentration, Beharrlichkeit, Sachkenntniss, Lese- und, dabei hilfreich, schreib - Erfahrung. Eine so kontextbezogene Disziplin wie die Komparatistik ist und bleibteine Textund Literaturwissenschaft" (Hoffmann 2000: 14). (Metinlere derinleşmek yoğunlaşmayı, kendine hâkim olmayı, kavramsal bilgiyi, okuma ve faydalı olacağından şüphe duyulmayan yazma tecrübesini gerektirir. Bağlama dayalı olan Komparatistik gibi bir bilim dalı kuşkusuz bir metin ve edebiyat bilimidir ve kuşkusuz öyle kalacaktır.)

\title{
4. DÜNYA EDEBİYATI VE KARŞILAŞTIRMALI ÇALIŞMALAR
}

Dünya Edebiyatı kavramının çıkış noktası kolaylıkla tespit edilecek kadar yenidir. Önce Christoph Martin Wieland (1733-1813)'ın notlarında ortaya çıkmıştır ve 1827'de Goethe tarafından kullanılmıştır. Bu kavramın içini tam olarak Goethe doldurmuştur diyebiliriz. O Dünya Edebiyatını ulusal üstü bir düzlemde, ulusları birleştirici bir perspektifle değerlendirmiştir. Dünya İletişimi (Weltkommunikation), dünya trafiği (Weltverkehr), dünya inancı (Weltfrömmigkeit) ve ulusal bilincin karşısına dünya bilincini (Weltbildung) yerleştirmeye çalışılması, bunların dışında kozmopolitlik dünya vatandaşı (Weltbürgertum) düşüncesi Goethe'nin gelecekle ilgili temennileri olmuştur (Hoffmann 2000: 17). Goethe'nin bu düşünceyle yürürlüğe koyduğu Dünya Edebiyatı düşüncesi uluslar arası bağlamda bütün halkları birbirine bağlayan bir düşünceden doğmuştur ve ilericilik iyimserliğine inanarak birinci derecede dünyanın eğitilmesi ile dünya iletişimi düşüncelerini hedeflemektedir (Zemanek-Nebrig 2012: 10). Goethe bu bakış açısıyla adeta Dünya Edebiyatı'nı ulusal edebiyatlar için bir üst kavram olarak görmektedir. Bununla ilgili Eckermann ile 31.1.1827 tarihinde yaptığı söyleşide şunu dile getirmiştir.

\begin{abstract}
"Nationalliteratur will jetzt nicht viel sagen, die Epoche der Weltliteratur ist an der Zeit, und jeder muß jetzt dazu wirken, diese Epoche zu beschleunigen. Aber auch bei solcher Schätzung des Ausländischen dürfen wir nicht bei etwas Besonderem haften bleiben und dieses für musterhaft ansehen wollen. Wir müssen nicht denken, das Chinesische wäre es, oder das Serbische, oder Calderon, oder die Nibelungen; sondern im Bedürfnis von etwas Musterhaftem müssen wir immer zu den alten Griechen zurückgehen, in deren Werken stets der schöne Mensch dargestellt ist. Alles übrige müssen wir nur historisch betrachten und das Gute, so weit es gehen will, uns daraus aneignen. "(Eckerman2016)

(Ulusal edebiyatın şimdi söyleyecek çok fazla şeyi yoktur, sırada artık dünya edebiyatı vardır ve herkes bu dönemi hızlandırmak için etkide bulunmalıdır. Fakat yabancı olanın değerlendirilmesinde özel bir duruma takılıp kalmamalıyız ve onu örnek teşkil eden bir şey olarak görmek istememeliyiz. Bizler asıl olanın Hıristiyan, Sırp, Calderon veya Niebelungen kökenli olanın olduğunu düşünmemeliyiz; örnek teşkil edecek bir şeyin gerekliliği için daima yapıtlarında sürekli güzel insanın anlatıldı̆̆ı eski Yunan'a geri dönmeliyiz. Bunun dışında kalanlara artık tarihe ait olarak bakıp, bunlardan mümkün olduğunca iyi olana uyum sağlamalıyız.)
\end{abstract}

Goethe'nin Dünya Edebiyatına dair bu anlayışı nicel olarak bütün edebiyatların zaman sınırlaması yapılmaksızın bütünlüğünü öne çıkarmaktadır. Onun kullandığı bu kavram klasik, kural, kanun veya hüküm olanla değil, daha çok modern ve güncel olanla ilintilidir. Bu düşünceye göre Dünya Edebiyatı kavramı Zemanek ve Nebrig'e göre çok gerçekçi değildir ama yine de somut fenomenler birbirleriyle karşılaştırılıyorsa ve genel teorik unsurlar elde ediliyorsa Komparatistik alanında algılanmalıdır (Zemanek-Nebrig 
2012: 10-11). Küreselleşmeye bağlı olarak Dünya Edebiyatı günümüzde canlılığını arttırarak sürdürmektedir. Goethe'nin "Weltliteratur" kavramının çevirisi olan "Dünya Edebiyatı"nın, edebiyatın Yeni Zelanda'dan İzlanda'ya kadar, beş kıtada da incelenmesi gerektiğini ima ettiğini belirten Wellek ve Warren'e göre aslında Goethe bununla bütün edebiyatların zaman içinde tek bir edebiyat haline geleceğini belirtmiştir. Onlara göre bu düşünce bütün edebiyatların büyük bir bütün olarak bir araya geldiği ve her ulusun kendine ait bir bölümü icra ettiği bir tasarımdır. Ancak böyle bir düşüncenin uygulanabilirliği çok zordur. En önemli sebep ise, doğal olarak hiçbir ulusun kendi şahsiyetinden feragat etmek istememesidir. Dünya Edebiyatının kullanıldığı bir başka anlam ise bütün dünyaya yayılmış klasik eserlerdir. Bu durumda bu kavram şaheserlerden meydana gelmiş, nitelikli edebî eserlerden seçme yapılarak oluşturulmuş büyük bir hazinedir (Wellek-Warren 1983: 59; Redeker 1986: 208).

Dünya Edebiyatı kavramı Komparatistik ile sık sık yan yana getirilmektedir; hatta Genel ve Karşılaştırmalı Edebiyat yani Komparatistik yerine 'Dünya Edebiyat Bilimi' (Weltliteraturwissenschaft) kavramını yerleştirmeye çalışanlar da olmuştur. Fakat asıl mesele Dünya Edebiyatı'nın Komparatistik'in bir alanının olup olmadığı veya bu alan ile özdeş olup olmadığı meselesidir. Hoffmann'ın aktardığına göre Victor KlempererKomparatistik'i dünya edebiyatının hayat bulması için bir tür resmiyet bağlamında açıklamıştır. Diğer taraftan Eduard Engel Dünya Edebiyatı'nı 1928'te zaman içinde kalıcı olan eserler ile ilintilemiştir (Hoffmann 2000: 16).

Matthew Arnold 1857 yılında Oxford Üniversitesinde yapmış olduğu bir sunumunda edebiyatın bütüncül yapısından bahsetmiştir. Onun bu konuşması Dünya Edebiyatı olgusuna farklı bir yaklaşım sunmaktadır. Ona göre Antik Yunan ve Ortaçağ Hiristiyan edebiyatları kendi içlerine kapalı, izole oluşumlardır. Bu durum Arnold'a göre yaşadığı çağın (19. yüzyıl ortaları) taleplerine ve beklentilerine hitap etmemektedir. Çünkü artık aralarında bir ilişkinin veya bir bağlantının olmadığı/kurulamayacağı bir edebiyat ya da olay yoktur. Ona göre insan hayatının her oluşumu ve bunların imgesel olarak yansımaları tek başına bir anlam ifade etmez; diğer olaylarla, başka edebiyatlarla bağlantılı olarak kavranılması gerekir. Bununla ilgili şunları dile getirmiştir: "Diğerlerinin nasıl ayakta kaldığını bilmek, bizim de nasıl ayakta kalabileceğimizi bilmemizi sağlar ve nasıl ayakta kalacağımızı bilmek, hatalarımızı düzeltip kurtulmamızı mümkün kılar. Bizim sorunumuz budur" (Arnold 1857: 2). (To know how others stand, that we may know how weourselvesstand; and to know how weourselvesstand, that we may correctourmistakes and achieve our deliverance-that is our problem).

Emin Özdemir Dünya Edebiyatı kavramını Ulusal Edebiyat kavramından hareketle tarif etmiştir. Onun açıklamaları ulusal edebiyatların sınırlarını muhafaza eden ve estetik kaygısının ön planda tutulduğu bütüncül bir tanımlama girişimi niteliğindedir. Özdemir'e göre dünya edebiyatının belirlenmesi öncelikle çok kapsamlı bir uğraştır ve karşılaştırmalı edebiyatın yöntemini gerektirir:

\footnotetext{
“Her ulusun kendi öz edebiyatına 'ulusal edebiyat' denir. Ulusal edebiyatlarn tümüne birden de 'Dünya edebiyatı' adı verilir. [...] Bu başka bağlamda da insan usunun ürettiği, çă̆lar boyunca değerini yitirmemiş, 'güzellik hazinesi' büyük kitapların toplamı demektir Dünya edebiyatı. Böylesine geniş bir kavramı bütün boyutlarıla inceleme ciltlerce kitap yazmayı gerektirir. Her ulusun edebiyatını karşılaştırmalı bir yöntemle ele almayı zorunlu kılar." (Özdemir 1980: 159)
} 
Özdemir'in bu açıklamalarından da anlaşılacağı gibi o, dünya edebiyatını belirlerken dünya çapında yaygınlıktan çok estetik özelliklerinden dolayı uluslararası enginlikte kalıcı bir konuma yerleşmiş olan eserlerden hareketle dünya edebiyatını tarif etmiştir. Bu eylemi gerçekleştirirken belli bir kültüre ait medeniyete gönderme yaparak ulusal edebiyatlar arasında ayırım, bir başka deyişle ötekileştirme yapmaz.

Dünya Edebiyatı kavramının gelişmesinde Goethe'nin döneminde çıkan ve kendisinin de yazılarını yayımlattığı dergilerin rolü büyük olmuştur. "Über Kunst und Altertum", "Eco", "Edinburg Reviev", "Le Globe" ve "La Revue Française" bunlardan bazılarıdır. Goethe bu yayın organları aracılığıyla yeni bir dönemin değişen ruhunu keşfetmiştir. Fransız İhtilal'inden sonra süreli yayınlar çoğalmış, dergiler modern çağın medyaları olmuşlardır. Bu yayın organlarının tek amacı klasik yazarların eserlerinden pasajlar yayımlamak değildi sadece, asıl amaç yaşayan yazarların birbirlerini tanımaları için zemin hazırlamak ve böylece topluma tesir etmekti. Dünya Edebiyatı bu bağlamda değişik uluslara mensup yaşayan yazarların toplumsal etki amacıyla fikir alış verişinde bulunmaları olarak algılanmaktadır (Hoffmann 2000: 17-19). Bir bakıma edebiyatta ortak bir ruhun yakalanmasıdır.

Annemarie Schimmel "Doğu-Batı Yakınlaşmaları" başlıklı kitabında Friedrich Rückert'ten (1788-1866) bahsederken dünya edebiyatına yönelme niteliği olan birçok açıklamada bulunmuştur. Schimmel'e göre Rückert Avrupa bilim ve edebiyat camiasında eşi benzeri bulunmayan bir şahsiyettir. Çünkü Rückert kendi zamanında çok sayıda şark dilindeki nazım biçimlerini Alman şiirine aktararak geniş çaplı bir külliyat meydana getirmiştir. Gazel biçimini ve Fars dörtlük sistemini Alman şiirine kazandıran odur ve Almancayı adeta bir tercüme hazinesi haline getirerek dünya edebiyatını Alman dilinde görme hayalini gerçekleştirmek için büyük çaba sarf etmiştir. "Onun tüm eserleri tek bir âlim tarafından değerlendirilemeyecek hacimdedir, ve hiçbir âlim de onları görmezlikten gelemez" (Schimmel 2012: 81) diyen Schimmel'e göre Rückert'in bu büyük çabasının asıl sebebi, onun dünya şiirine yüklediği dünya barışına yönelik bir misyondur (Schimmel 2012: 82). Bu açıklamadan anlaşılabileceği gibi Rückert'e göre dünya şiirinin, bir başka deyişle dünya edebiyatının asıl amacı dünya barışı olmalıdır. Bu perspektiften bakıldığında edebiyat sanatı ve bilimine farklı ülke ve kültürlerin birbirlerini tanıyarak öz benlikleri çerçevesinde uluslar arası bir platformda yan yana yer edinebilecekleri bir değer yüklemiştir diyebiliriz. Rückert Doğu ve Batı edebiyatları arasında ayırım yapmaz, Doğu edebiyatlarında gördüğü değeri Alman edebiyatını zenginleştirmek için kullanmak istemiş ve bunun için büyük bir çaba sarf etmiştir. Ancak AntalSzerb gibi dünya edebiyatı kavramının sınırlarını belirtirken milletler arasında "kültürlü" ve "kültürsüz" ayırımını yaparak adeta ötekileştirme eyleminde bulunan ve dünya edebiyatını İncil merkezli olarak eski Yunan, Latince ve Germen dilleri ile sınırlayan (Szerb 2008: 11-12) zihniyetin, Rückert'in hoşgörü ortamıla hiç ilgisinin olmadığını belirtmekte yarar vardır.

Ulusların basın yoluyla teşvik edilerek birbirlerini tanımaları, yazarlar ve edebiyatçıların irtibat halinde olmalarıyla yaygınlaşmasında Goethe'nin de belirttiği gibi çeviri büyük rol oynamıştır. Ona göre çeviri Dünya Edebiyatı'nı teşvik eden bir faaliyettir. Bir dilin özelliği aynı zamanda o ulusun özelliğidir ve bir dilin dehası orijinal ile çevirinin karşılaştırılmasında bariz bir şekilde ortaya çıkar. Goethe'nin ideal dünya edebiyatı düşüncesine bu yüzden ulusların daha iyi tanınması için aktif çeviri eleştirisi de dâhildir. Ayrıca diğer ülkeler hakkında izlenim kazandıran, seyahatleri konu alan seyahatnameler Dünya Edebiyatı bağlamında Goethe için önemli bir tür olmuştur. Bütün bunların ötesinde 
Goethe'nin Dünya Edebiyatı anlayışı ilericilik sürecine bağlı bir terimdir. Bu süreç ağırlıklı olarak uluslararası gelişme ve küresel iletişimle ilişkilidir. Bu yüzden onun bu kavramdan kastettiği öncelikle güncelliktir. Goethe'ye göre ulusların fikir alışverişinde bulunmaları geleceğe açılan kapılardır ve klasik, kurumsallaşmış veya nizamname (Kanon) niteliğindeki kalıcı olana bağımlı değildir. Bu düşünceye göre Dünya Edebiyatının gelişim süreci durdurulamaz bir olgudur. Fakat hangi eserlerin buna dâhil edilebileceği de meçhuldür. Çünkü güncel olan nasıl sürekli değişiyorsa, Dünya Edebiyatı da sürekli buna bağlı olarak değişmektedir. Çünkü Hoffman'ın aktardığına göre Hans Robert Jauß’un da belirttiği gibi modernitenin kaderi demode olmaktır. Aynı durum Dünya Edebiyatı için de geçerlidir, muğlâklığı ve geçiciliği ile modern olmanın bedelini öder. Goethe'ye göre kavram aynı kalır fakat içeriği sürekli bir değişim halindedir. O klasik anlamdaki nizamname (Kanon) taraftarı değildir, edebiyat anlayışı daha ziyade yazın (Schrifttum) anlamındadır ve estetik tandanslı poetika ile örtüşmesini önemsemez (Hoffmann 2000: 17-19).

René Etimble (1909-2002) Alman kökenli olan Dünya Edebiyatı kavramını öncelikle dünyanın edebiyatı olarak anlamaktadır ve bunu doğrudan karşılaştırmalı edebiyatın çalışma alanıyla ilintilemiştir. Böyle bakıldığında dünyada yazılmış olan her şey bu alanın özünü teşkil etmektedir. Bu oldukça geniş bir alandır ve bilişim teknolojilerinin ileri bir safhada olduğu günümüzde bile ulaşılması imkânsız bir enginliğe sahiptir. Özellikle yüzyıl dönümünde geniş çaplı edebiyat tarihleri kaleme alınmıştır. Otto Hansers'in “Edebiyatın Dünya Tarihi" (Weltgeschichte der Literatur), Ardold Bartels'in "Dünya Edebiyatına Giriş" (Einführung in dieWeltliteratur) ve Paul Wieglers'in "Yabancı Dildeki Dünya Edebiyatı Tarihi" (Geschichte der Fremdsprachigen Weltliteratur) bunlardan bazılarıdır. Bu eserlerde Goethe'nin teorisinden farklı olarak yazın (Schrifttum) yerine estetik kaygılarla kaleme alınmış olan güzel edebiyat (Belletristik) temel alınmıştır. Fakat bu sınırlama da üretimin çokluğu karşısında yetersiz kalmaktadır. Günümüzde dünyanın gelişmesine paralel olarak ilerleyen edebiyat karşısında onun tarihini yazmak imkânsız bir hal almıştır diyebiliriz. Edebiyat eserlerini derinlemesine incelemek işi daha da zorlaştırmaktadır. Fakat uygulama ile ilgili olan bu durum Dünya Edebiyatı düşüncesinin niceliğine zarar vermemelidir. Etimble'ye göre herkesin kafasında özel bir kütüphanesi vardır ve herkesin kendisine seçtiği kitaplar bağlamında bir dünya edebiyatı görüşü mevcuttur. Bu düşünce Hermann Hesse'nin Dünya Edebiyatı düşüncesiyle büyük ölçüde örtüşmektedir. Hesse'nin 1929 yılında yayımladığı "Eine Bibliothek der Weltliteratur" (Dünya Edebiyatı Kütüphanesi) başlıklı çalışması bir bakıma yazarın kişisel dünya edebiyatı nizamnamesini (Kanon) teşkil etmektedir. Edebiyatın kültürel önemi, Goethe'nin Dünya Edebiyatı bağlamında da belirttiği gibi, fikirlerle gerçekleşen bir bilgi paylaşımıdır. Eğer okunulan şey ile ilgili bir fikir alış verişi veya bir iletişim gerçekleşecekse etüt edilen yazınsal yığın kısmen de olsa birbiriyle örtüşmelidir. Bu durumda tespit edilmiş nizamname niteliğinde bir külliyat (Kanon) iletişim için kaçınılmazdır. Bu aynı zamanda edebiyatın anlaşılması ve etkisi için vazgeçilmez bir yaratıcılıktır. Ancak alan o kadar genişlemiştir ki bu enginlik karşısında bir edebiyat haritasına sahip olmamı gerekirken elimizde olan okunması mümkün olmayan labirentvari bir metin yığınıdır. Bu durum karşısında Goethe'nin Dünya Edebiyatı anlayışı daha net ve isabetlidir. Çünkü o edebiyatı öncelikle genel bir olgu olarak kabul eder ve özel olana yönelmeyi gerekli görmez. Onun edebiyat anlayışı, katı kurallar çerçevesinde bakıldığında, aslında edebiyat da değildir ve dünyayı sadece belli bir an itibariyle aktüalite çerçevesinde kabul eder (Hoffmann 2000: 22). Gerek Goethe'nin konuyla ilgili düşünceleri, gerekse nicel Dünya Edebiyatı anlayışı, geçmişte olduğu gibi günümüzde de tartışılmaya devam 
edilmektedir. Her iki anlayış da modernitenin paradoksları arasında yerini almış durumdadir.

Grimm sözlügündeki Dünya Edebiyatı maddesine bakıldığında, mevcut olan açılamalar günümüzdeki genel kanı ile örtüşür niteliktedir. Grimm bu kavramı bütün halkların ve zamanların edebiyat üretimi ve ulusal kitleleri aşması olarak belirleyerek bütün kültürler ve uluslar için ortak bir değer haline gelmiş eserlerin toplamı olarak tarif etmiştir:
"in sonderheit für die auslese der literarischen schöpfungen aller völker und zeiten, die - über den jeweiligen nationalen publikumskreis hinauswirkend-zum gemeinsamen klassischen literaturgut aller kulturvölker geworden ist; 'jene auserlesene literatur, die sich eine übernationale und überzeitliche gültigkeit errungen hat"(Grimm 2016)
(Bütün halkların ve zamanların özel ve seçilmiş edebiyat yaratıları - söz konusu ulusal kitlenin dışına hitap ederek- bütün kültür halklarının ortak klasik edebiyat değerleri haline gelmiştir; öyle ki ulusallığı ve zamanı aşarak özel bir edebiyat geçerliliğini hak etmişlerdir.)

Bu durumda Dünya Edebiyatı dil ve ulusal sınırları aşmış yazar ve eserleri kapsamaktadır. Fakat bu kavramdan bütün ülke ve zamanların edebiyatlarını anlayabilmek için öncelikle edebiyat kavramına yönelik bir dönüşüm gereklidir. "Yazll olanın kaleme alınma olayı, kullanım amacına göre biçim değiştirecektir" (Gadamer 2002: 21) diyen Hans Georg Gadamer'e (1900-2002) göre edebiyatın anlattığı dünya, bu dünyanın yazıya aktarılma süreci ile hitap ettiği kitle ve onun alımlaması aynı değildir. Ona göre edebiyatın zaman üstü bir dili vardır ve dünyanın değişimine kalıcılıkla ayak diretmeye çalışır. Gadamer'in bu düşüncesi nizamname (Kanon) eğilimli Dünya Edebiyatı düşüncesini destekler niteliktedir. Ancak günümüzde bu kavramın içi adeta boşaltılmış durumdadır. Özellikle politicalcorrectnes'in (farklı dil, din, kültür ve cinsiyete sahip olan kişilerin incitilmemesini ifade etmek için kullanılan bir kavram) kültür ürünlerine de tatbik edildiği Amerika'da Genel Edebiyat kavramının kurumsallaşması sorgulanmaktadır. Avrupa kökenli beyaz adamın kültürünün sadece bir kısmının öne çıkarılması Dünya Edebiyatı anlayışına şüphe düşürmektedir. Bu durum karşısında bir nizamname (Kanon) gerekliliğini savunmak güven duygusuyla doğrudan ilintilenmekte ve şüpheli karşılanmaktadır (Hoffmann 2000: 24-25). Ayrıca her nizamname (Kanon) arka planda yer alan okunmamış eserler yığınının yer aldığı az sayıda eserin okunmasıyla meydana geldiği de bir gerçektir.

Fatma Erkman-Akerson Dünya Edebiyatı kavramını açıklamaya başlamadan önce evrensellik konusuna açıklık getirme gereği duymuştur. Bu kavramı "Edebiyat ve Evrensellik" başlı̆ğ altında ele alır. Ona göre edebiyat öncelikle bir kültür sistemidir ve tüm dünya edebiyatı için geçerli olan evrenselleri barındırmaktadır. Göstergebilim ise edebiyattaki evrenselleri iletişim ve kültürel sistem bağlamında ele alır. Ona göre edebiyatın evrenselliği ile ilgili iki görüş söz konusudur. Birinci görüş edebiyatın genel geçer bir anlatı örgüsünün olup olmadığı düşüncesine dayanır ve dünyadaki edebi metinlerin ortak yanlarını bulmaya çalışır. İkinci görüş ise küreselleşmeye odaklanarak iyi bir okurun ulusal edebiyatın sınırları ötesinde dünya edebiyatından haberdar olması gerektiğini savunur. Edebiyatın yayılımı ekseninde metinlere nasıl ulaşılabileceğini ve anlaşılmaları için araştırmalarda bulunmayı öngörür. Evrenseller her toplumda/kültürde var olan ortak özelliklerdir. Ancak toplumların birbirlerini etkileyerek, taklit veya çeviri yoluyla meydana gelen özellikler evrensel sayılmaz. Akerson bunları ödünçleme olarak nitelemiştir (Akerson 2010: 38). Bazı toplumlar birbirlerinden etkilenmeden benzer toplumsal yapilara sahip olabilirler ve edebiyatlarında benzerlikler görülebilir. Örneğin derebeylik sisteminde veya 
göçebe olarak yaşamış toplumların metinleri "daha kalıplı, daha katı, kahramanları da daha idealize edilmiş" (Akerson 2010: 39) tiplerdir. Edebi türlerin ve ortak konuların değişik toplumlarda benzer olarak ortaya çıkışı evrensel bir özelliktir. Örneğin sevgililerin birbirlerine kavuşamama konusu tüm dünyada vardır. Şiir türü ise tüm dünyada övgü, törensel veya eğlence amaçlı ortaya çıkmış ve belli bir toplumsal sistemde değerlendirilmiştir. Günümüzde küreselleşmeye bağlı olarak ulusal edebiyatların yanı sıra Dünya Edebiyatından da söz edildiğini belirten Akerson, karşılaştırmalı edebiyatçıların benzer toplum ve kültürel olayların edebiyata yansımasını araştırdıklarını dile getirmiştir. Sömürge ve gelişmekte olan ülkelerin Batı edebiyatlarından etkilenmeleri son zamandaki çeviri faaliyetleriyle değişmiştir. Artık herkes herkesin edebiyatı hakkında fikir sahibi olabilmektedir. Ancak hepsi hakkında bilgi sahibi olabilmek metin ve dil sayısının çokluğundan dolayı imkânsız hale gelmiştir. Ayrıca İngilizce dünya çapında egemenliğini korumakta ve nelerin çevrileceği büyük ölçüde yayın evlerinin tekelinde bulunmaktadır (Akerson 2010: 40). Öncelikle edebiyatın bir kültür sistemi olduğu üzerinde duran AkersonGöstergebilim'e (Semiotik) kültür odaklı evrenselleri, bir başka deyişle ortak özellikleri araştıran bir görev yüklemiştir. Bu bağlamda dünya edebiyatına göndermede bulunan araştırmacı okuyucu düzeyine değinerek ulusal edebiyatın dışına çıkma gerekliliği üzerinde durmuştur. Ancak küreselleşmenin etkisiyle İngilizcenin dünya edebiyatını belirlemede etkin olduğunu belirten Akerson adeta sadece niteliğin değil, dominant kültürün etkisine işaret ederek dünya edebiyatının belirlenmesiyle ilgili bir gerçeğe işaret etmiştir. Bu durumdan ulusal filolojilerin de kendilerine bir ders çıkarmaları gerekliliği doğmaktadır. Bu bağlamda Komparatistik ulusal filolojilere önemli katkılarda bulunabilecek disiplinsel donanıma sahiptir.

\section{SONUÇ}

Komparatistik yapısından kaynaklanan disiplinler arası özelliğinden dolayı çağımızın ruhuna işlemiş olan postmodernizmin çoğulcul yapısına nüksetmiş olan çok katmanlı estetik anlayış karşısında, belki de daha önce hiç olmadığı kadar, büyük beklentilere maruz kalmaktadır. Sürekli karşılıklı etkileşim ve bağımlılık içinde olan Genel Edebiyat Bilimi ile Karşılaştırmalı Edebiyat Bilimi'nin bir bileşkesi, birlikte hareket ederek meydana getirdikleri bir disiplin olan Komparatistik, tarih boyunca değişik etkilere maruz kalmış olan Türk edebiyatının engin sınırlarının tanıtılmasında, edebiyat incelemesi araç ve metotlarıyla Türk edebiyat tarihi yazıcılığının gelişmesinde ve buna bağlı olarak dünya edebiyatı içinde yerinin belirlenmesinde sağlayacağı imkânlardan yararlanmanın getireceği faydalar su götürmez bir gerçektir. Ulusal filolojilerin kendi alanlarını desteklemek için karşılaştırma eylemlerinden gün geçtikçe daha çok faydalanarak Komparatistik araçlarını kullanmaları bu düşünceyi destekler niteliktedir. Çünkü Komparatistik edebiyat bilimi çatısı altında yer alan başlı başına bir disiplin olmakla birlikte ulusal filolojilere önemli katkılarda bulunma niteliğine sahiptir.

Belki de insanlık tarihi kadar eski olan karşılaştırma eylemi bilimsel bir metot haline geldiğinde birçok bilim dalının uygulama alanında yer bulmuştur. Bu alanlardan birisi de Filolojidir ve Komparatistik karşılaştırma metodunu kendi bilimsel varlığı için temel çıkış noktası olarak kabul etmektedir. Edebiyat çalışmalarındaki karşılaştırma hiçbir zaman asıl gaye değildir, öncelikli olarak eşdeğer ve karşıtlık mukayeseleri ile bilgiye ulaşmak ve analitik düşünceyi desteklemek amaçlanmaktadır. Karşılaştırmalı edebiyat çalışmalarında çıkış noktası olan genetik veya tipolojik mukayeseler değişik disiplinlerden de yararlanarak 
metin odaklı incelemeleri insan algısına uygun olacak şekilde somutlaştırmayı amaçlamaktadır.

Genel Edebiyat Bilimi daha çok Felsefe alanına dâhil olan estetik konusunu edebiyatın malzemesi ile birleştirir, böylelikle ulusal sınırların ve alan araştırmalarının dışında evrensel bir teori üretimiyle ilgilenir. Fakat bu evrenselliğin ulusal edebiyatlara da önemli katkılarda bulunduğu göz ardı edilmemelidir. Çünkü ulusallaşmanın birinci yolu öncelikle dişarıya açılmaktır.

Edebiyat ve toplum ilişkisi yakın zamandan beri daha büyük bir ilgiyle sorgulanmaktadır. Bu amaçla disiplinler arası yapılan karşılaştırmalı çalışmalar, temel bir üslup/tarz meydana getirmektedir. Ancak bu bağlamda yürütülen araştırmalardan üretilecek olan teorilerin çıkış noktaları, edebiyat eserlerini taban alan değişik dil ve kültür alanlarında yürütülen rasyonel çalışmalar olmalıdır. Edebiyat ve toplum meselesini sadece tek bir dildeki edebiyata dayanarak genel bir teori arayışına girmek anlamsız bir uğraş olur. Bu noktada komparatistik bir bakış açısına sahip olmak gereklidir. Çünkü kesin yargılara ancak değişik görüş ve eserleri kıyasladığımızda ulaşabiliriz.

Genel Edebiyat Bilimi bütün edebiyatları kapsayan teoriler geliştirir, kavram ve genel prensipler üretir, bunun için edebi akımları inceleyerek çalışma alanına eser ve okuyucu kitlesini dâhil eder. Bu noktada Genel Edebiyat Bilimi edebiyatın dışına çıarak Toplumbilim ve Psikoloji gibi alanlara da yönelmek zorunda kalır. Bu durum Komparatistik'in disiplinler arası niteliğini teşkil eder ve buna ayak uyduramayan ulusal filolojilerin nasıl bir yol izleyecekleri belirsizdir. Günümüz insanı teknolojinin gelişmesiyle iletişim ve ulaşım imkânlarının artmasıyla her an farklı kültürlerle temas halindedir ve popüler kültürlerin baskılarına maruz kalmaktadır. Edebiyatların bu çoklu kültürel sistem içinde kaybolma tehlikesini bertaraf etmek için Komparatistik önemli imkânlar sunmaktadır. Günümüzde ulusal edebiyatların güçlenmesi için Genel ve Karşılaştırmalı Edebiyat'ın (Komparatistik) sağladığı imkânlardan yararlanmaları keyfiyetten öte bir durum teşkil etmektedir. Ancak bunun için -karşılaştırmalı edebiyat çalışmaları yapacak olan araştırmacıların- öncelikle bir, hatta mümkünse birden fazla yabancı dil donanımına sahip olmaları birincil şartlardan birisidir.

Ülkemizde genellikle Komparatistik ile aynı kabul edilen, sıklıkla onun yerine kullanılan Karşılaştırmalı Edebiyat kavramı bir disiplin olarak bu günkü haline gelene kadar birçok aşamadan geçmiştir. Genel Edebiyat Bilimi edebiyatın teorik yüzüyle uğraşırken Karşılaştırmalı Edebiyat Bilimi ulusal edebiyatların, edebi akımların ve eser çevirilerinin karşılaştırılmasını esas alır. Bunu gerçekleştirmek için ortak konu ve motif tespit eder, edebiyatın diğer sanat ve bilim dallarıyla, başka medyalarla olan ilişkisini mukayese yoluyla inceler. Genel ve Karşılaştırmalı Edebiyat Bilimleri farklı alanlar olmalarına rağmen her iki disiplinin de birbirlerine olan bağımllıkları ve ortak hedefleri göz önünde bulundurulduğunda sürekli birlikte anılmaları hiç şaşırtıcı değildir.

Ulusal edebiyatların birbirleriyle karşılaştırılmaları onların gelişmişliğini ve dünya edebiyatı içinde yerlerinin belirlenmesini sağlar. Bu sayede estetiğin yeni kuralları da tespit edilebilir. Hatta güzelliğin yeni kurallarının ancak karşılaştırılarak belirlenebileceğini savunanlar vardır. $\mathrm{Bu}$ bağlamda milli edebiyatların dünya edebiyatı içinde konumlandırılmalarında Karşılaştırmalı Edebiyatın estetik kurallarının belirlenmesinde gösterdiği katkının payı göz ardı edilmemelidir. Karşılaştırmalı Edebiyat dünya edebiyatının beslendiği ve varlığını borçlu olduğu yönlendirici güçlerden biridir adeta. Kültürbilimsel sorgulama Komparatistik için vazgeçilmez bir husustur. Bir eser 
Karşılaştırmalı Edebiyat aracılığıyla ulusal sınırların ötesine taşınır ve daha akılcı bir bağlam içinde değerlendirilebilir. Edebiyatın yapısı, temel ve genel ilkeleri, toplum ve diğer sanatlarla olan ilişkisi ve sistematik-kuramsal konular sadece ulusal üstü bir çalışma disipliniyle çözülebilir. Ancak bu sayede ulusal edebiyatlar için karakteristik unsurlar tespit edilebilir. Sadece tek bir edebiyattan hareketle genel bir edebiyat teorisi geliştirmek analitik düşüncenin de kabul etmediği gibi başarısızlığa mahkûm bir uğraştan öteye gidemez. Ulusal edebiyatların gerçek nitelikleri ve kapsamları ancak karşılaştırma neticesinde ortaya çıar. Fakat bu durum Komparatistik'in ve milli edebiyatların bağımsızlıklarına engel bir durum olarak algılanmamalıdır. Çünkü Komparatistik ulusal edebiyatların bittiği yerde başlar ve onların verilerini farklı bir anlamda araştırma alanı haline getirerek ulusal edebiyatları bir üst aşamadaki konuma yerleştirebilir ve aynı zamanda bağımsız bir disiplin olarak kendi faaliyetlerini sürdürebilir.

Klasik filolojilerin Komparatistik'e yönelttikleri en yaygın eleştiri bir eserin karşılaştıııldığında, itibarının azalacağına dairdir. Oysa bunun bir yanılgı olduğu kesindir. Çünkü bir eserin özgünlüğü ancak diğer eserlerle karşılaştırıldığında anlaşılabilir. Aslında bir eser uluslararası bir platforma taşındığında yaygınlığı daha geniş kitlelere taşınarak takdir edilme olasılığı artar ve böylelikle kıymeti ve saygınlığı üst seviyeye taşınır. Ayrıca karşılaştırmalı yöntem bilgisi ulusal filolojilere küçümsenmeyecek derecede teorik kaynaklar sunmaktadır. Aynı zamanda metot gelişimini sağlayarak, ulusal filoloji derslerine yeni ufuklar açar.

Dünya edebiyatına mal olmuş eserlere bakıldığında bunların ulusal olduğu gibi evrensel değerlere de sahip çıarak uluslararası düzeyde diğer edebiyatlarla irtibatlı olan yapıtlar olduğunu kolaylıkla görebiliriz. Bu irtibatı sağlayacak olan öncelikle karşılaştırmalı yöntem bilgisine sahip ve yabancı edebiyatlara vakıf olan edebiyat eleştirmenleridir; kısacası ilericilik iyimserliğine sahip komparatistlerdir. Dünya Edebiyatı kavramıla sıklıkla yan yana getirilen Komparatistik aynı zamanda çeviri faaliyetlerinin önemine vakıf ve bu tür çalışmaları teşvik eden bir alandır. Karşılaştırmalı çeviri çalışmaları bunu çok iyi göstermektedir. Çeviri faaliyetleri dünya edebiyatını besleyen bir başka önemli alandır demek yanlış olmayacaktır. Ancak güncelliğin değişimi nasıl beklenilen bir durum ise Dünya Edebiyatının değişimi de buna bağlı olarak kanıksanmalıdır. Modernliğin kaderi nasıl demode olmaksa Dünya Edebiyatı da sürekli bir değişim içinde olduğundan bir bakıma bedel öder. Bundan kastedilen dünya edebiyatına mal olmuş bir eserin bir müddet sonra değersizleşeceği değildir. Nitekim Dünya Klasikleri diye adlandırılan yapıtlar varlıklarını asırlar boyu sürdürmeye devam etmektedirler. Kastedilen şey popülerliğin kendi doğasında var olan hareketlilikten başka bir şey değildir. Ancak bir noktaya işaret etmekte fayda vardır. Çağımızda teknolojinin gelişimine bağlı olarak küreselleşmenin hız kazanması Dünya Edebiyatının belirlenmesinde sadece niteliğin değil, aynı zamanda ekonomik, ticari, sosyoekonomik etkenler başta olmak üzere birçok sebepten dolayı baskın bir kültür olgusunun da etken olduğudur. İngilizcenin dünya çapındaki etkisi buna örnek olarak gösterilebilir. Baskın bir kültür etkisiyle diğer kültür ve edebiyatların ikinci sınıf olarak görülmemesi konusunda Komparatistik'in sağlayacağı katkılar göz ard1 edilmemelidir.

Türk edebiyat tarihine bakıldığında Doğu ve Batı kaynaklı yabancı tesirlerin sürekli var olduğunu kolaylıkla görebiliriz ve bu durum Komparatistik için uygun bir çalışma sahası meydana getirmektedir. Karşılaştırmalı eser analizlerinin Türk edebiyatına gerek teori, gerekse eleştiri ve uygulama bakımından büyük katkılar sağlayacağını kabullenmekte 
tereddüt etmek ve gecikmenin getireceği kültürel dezavantajlar telafisi mümkün olmayan sonuçlar doğurabilir.

\section{SUMMARY}

Comparatistics is faced with an immense expectation more than ever due to a multilayer aesthetic conception that has already penetrated the pluralist structure of postmodernism, which makes it an undeniable fact that Comparatistics as a compound discipline of literature and comparative literature will provide great benefits for the improvement of both Turkish literature and History of Turkish Literature via literary investigation methods. On the other hand, the growing interest of national philologies in the use of Comparatist instruments in order to support their disciplines appears to be a valid endorsement for such an argument since Comparatistics overtly possesses the potential of substantial contribution for the national philologies while being an independent discipline of literature. Most probably, the act of comparison which is as old a deed as human history has gained a place for itself in various disciplines when it consequently became a scientific method for investigation. Philology as one of these disciplines acknowledges Comparatistics' method of comparison as a substantial ground for its existence. Yet, the process of comparison opted for in literary studies is on no account the ultimate objective; it is rather for developing analytical thinking. The genetical or typological comparisons on which comparative literature studies are grounded target embodiment of text-oriented investigations via utilizing various disciplines in order to make them appeal to human perception.

Literature as a general science integrates the aesthetic concept which is rather the subject of philosophy with its own materials and therefore it is intrigued by the codification of a universal theory beyond national borders and literature studies. Still, this universality also contributes considerably to national literatures since the premise of nationalism is to be in harmony with the process of expansion towards outer world.

The rapid technological progression which facilitates all means of communication makes today's individual to be exposed to an intensive contact with multifarious cultures but most importantly to a dominant popular culture effect. At this juncture, Comparatistics appears to be a good candidate to provide the entailed substantial resolution to overcome the prospect of being devoured by this multi-cultural system, which indeed seems to be a must rather than a choice for national literatures to utilize the opportunity that literature and Comparatistics provide them with.

The comparison of the national literatures, on the other hand, accentuates both their development and their place in world literature while providing an opportunity to codify the new rules of aesthetics. After all, there are those who even argue that these new rules of aesthetic could only be determined by means of comparison. In this sense, the contributions of Comparatistics to the codification of the rules of aesthetics should also be borne in mind when determining the place of national literatures within world literature. Comparatistics, to this end, stands out to be one of the fundamental sources that world literature subsists on as it most frequently utilizes cultural criticism as an indispensable instrument whereby it evaluates a piece of work beyond national boundaries in a more rational context. What is more, it can only be a discipline with a beyond-national perspective that may convey a resolution to cases such as the true nature of literature, its fundamental principles, its relationship with arts and finally other systematical-conceptual issues. In this way, a top- 
down approach would make it probable to understand the characteristic elements of national literatures instead of a failure induced by developing a general literature theory resting on a single national literature based on a bottom-up approach. The characteristics and extents of national literatures emerge as a result of a comparison process, which should never be understood as a threat that makes Comparatistics and national literatures mutually exclusive in as much as Comparatistics begins to function where national literatures cease and it may elevate their status to the next level via transforming their data into a new kind of investigation area while maintaining its own independence as a discrete discipline.

The commonplace that classical philologies blame Comparatistics for is the misconception that a piece of work would lose its dignity when it is compared to another. On the contrary, the genuineness of a work is only apprehensible through comparison. Besides, when a literary work is conveyed to an international platform, its prospect of appreciation becomes more probable since it becomes enabled to reach quite a wider range of masses. This, in fact, carries its dignity and importance to an upper level. Aside from all these, comparison methodology would provide considerable number of theoretical sources to the interests of national philologies while facilitating methodological development and opening new horizons for national philology courses.

It is conspicuous that the celebrated works of world literature have national identities besides adopting universally common values and having connection with other literatures on an international plane. Those who will realize this connection are literary critics with knowledge of comparison methodology and foreign literatures; in short, comparatists with progressive optimism.

Comparatistics which is simultaneously pronounced with the term "world literature" is a discipline attaching importance to translation process while encouraging them. While the comparative translation studies stand out to be a clear demonstration of this argument, they also they constitute another source for the improvement of world literature. However, it is so usual to await the change of what is contemporary as it is so for the change of world literature. In other words, if it is a faith for modernity to become old fashioned in the course of time, then it is the world literature that is due to pay for the change it is subject to. The point here is not that a piece of literary work that has become a "world literature" would depreciate its value; yet, the contributions which Comparatistics would make lest there should be a second- class label put on other cultures and literatures because of a dominant culture should not be disregarded. 


\section{KAYNAKÇA}

Akerson, Fatma Erkman (2010). Edebiyat ve Kuramlar. İstanbul: İthaki Yay.

Arnold, Matthew (1857). On The Modern Element In Literature. $\quad$ https://tr.scribd.com/doc/11554174/Matthew-Arnold-On-the-ModernElement-in-Literature [23.03.2018].

Aytaç, Gürsel (2003). Genel Edebiyat Bilimi. Ankara: Say Yay.

Aytaç, Gürsel (2003). Karşılaştırmalı Edebiyat Bilimi. Ankara: Say Yay.

Dyserinck, Hugo (1991). Komparatistik-Eine Einführung. Bonn: Bouvier Yay.

Eckermann, Johann Peter. Gespräche mit Goethe in den letzten Jahren seines Lebens. Kapitel 106. http://gutenberg.spiegel.de/buch/-1912/80 [2.1.2016].

Eckermann, Johann Peter. Gespräche mit Goethe in den letzten Jahren seines Lebens. Kapitel 106. http://gutenberg.spiegel.de/buch/-1912/106 [1.1.2016].

Gadamer, Hans Georg-Kuhn, Helmut vd. (2002). Edebiyat Nedir?çev. Şahbender ÇoraklıAhmet Sarı. Erzurum: Babil Yay.

Green, Frederic Chrles (1939). Minuet-A Critical Survey of Frange And English Literary Ideas in the Eighteenth Century. Londra: J. M. Dent and Sons Yay.

Grimm, Jacob - Wilhelm. Deutsches

Wörterbuch. http://woerterbuchnetz.de/DWB/?sigle=DWB\&mode=Vernetzung\&lemid=G W16983\#XGW16983 [2.1.2016].

Hoffmann, Angelika Corbineau (2000). Einführung in die Komparatistik. Berlin: Erich Schmidt Yay.

Johan, Rahman (2004). Comparative Literature- A Case Of Shaw And Bharatendu. Yeni Delhi: Sarup \& Sons Yay.

Karataş, Turan (2011). Ansiklopedik Edebiyat Terimleri Sözlüğ̈̈. İstanbul: Yedi Gece Kitapları Yay.

Müller, Dyes Klaus (1996). „Gattungsfragen“, Grundzüge der Literaturwissenschaft. ed. Arnold, Heinz Ludwig-Detering, Heinrich. Münih: DTV Yay.

Özdemir, Emin (1980). Türk ve Dünya Edebiyatı. Ankara: Ankara Üniversitesi S.B.F. Yay.

Petraraca, Francesco (2016). Canzoniere. çev. Kemal Atakay. İstanbul: Everest Yay.

Rederek, Horst (1986). Edebiyat Estetiği. çev. Aziz Çalışlar. Ankara: Kuzey Yay.

Remak, Henry (1961). "Comparative Literature-Its Definition and Funktion". Comparative Literature: Method and Perspective. ed. Stallknecht, Newton P.-Frenz, Horst. Carbondale: Southern Illinois Universty Press Yay.

Sakallı, Cemal (1998). "Karşılaştırmalı Yazınbilim Kuramları ve Yöntem Sorunu". Karşılaştırmalı Edebiyat Araştırmaları. ed. Ali Osman Öztürk. Konya: Selçuk Üniversitesi Vakfı Yay.

Schimmel, Annemarie (2012). Doğu-BatıYakınlaşmaları-Avrupanın İslam Dünyasıyla Karşılaşması. çev. Hüseyin Ağuiçenoğlu. İstanbul: Avesta Yay.

Szerb, Antal (2008). Dünya Yazın Tarihi. çev. Vural Yıldırım. Ankara: Dost Yay.

Zemanek, Evi-Nebrig, Alexander (2012). Komparatistik. Berlin: Akademie Yay.

Zima, Peter (1992). Komparatistik. Tübingen: Francke Yay. 